\title{
Geological perspectives of the East Greenland continental margin
}

\author{
HANS CHRISTIAN LARSEN
}

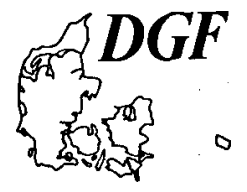

\begin{abstract}
Larsen, H. C.: Geological perspectives of the east Greenland continental margin. Bull. geol. Soc. Denmark, vol. 29, pp. 77-101, Copenhagen, June 10th, 1980. https://doi.org/10.37570/bgsd-1980-29-04

The East Greenland continental margin can be divided into a northern area showing evidence for plate separation and suturing of Hudsonian, Grenvillian and Caledonian ages followed by post -Late Caledonian molasse sedimentation and Mesozoic rifting, and a southern area which apparently formed a cratonic block from the Early Proterozoic to the Middle Cretaceous. The whole margin was finally separated from the NW European margin by sea floor spreading in the latest Paleocene to earliest Eocene and now forms a rifted passive margin. The Tertiary consists of thin pre-drift sediments overlain by 1-7 km of Late Paleocene basaltic lavas extruded immediately prior to active spreading. Subsequent subsidence of the shelf led to accumulation of $2-8 \mathrm{~km}$ of post-basaltic sediments offshore whereas the land area wasuplifted 1-2 km. Initiation of spreading along the Kolbeinsey Ridge during the lateOligocene was accompanied by renewed tectonism within the middle part of the margin. Finally the shelf was characterized by strong progradation during the Miocene. Backwards rotation of the inferred ocean-to-continent transition, through the total pole of opening, favours a slightly modified Talwani and Eldholm pole which provides a pre-drift fit of the two margins with no major overlap or gaps between the southern tip of Greenland and the Greenland-Senja Fracture Zone. Comparison of the Greenland margin and the Voring Plateau implies a genesis for the latter, different from that proposed by Talwani andEldholm. Minor revisions of the spreading history are presented including repeated westward displacement of the southernmost part of Mohns Ridge between anomaly 24 and 21 , commencement of spreading around Kolbeinsey Ridge not later than anomaly 6 and associated activation of the recent active part of Jan Mayen Fracture Zone (JMFZ), to the north of the previous active part. The area between the fossil part of JMFZ and the recent active part including the northern part of Jan Mayen Ridge is suggested to have formed around a southern extension of Mohns Ridge active until about anomaly 6 and the predicted position of the extinct axis correlates well with bathymetry.
\end{abstract}

Hans Christian Larsen, The Geological Survey of Greenland, Østervoldgade 10, 1350 Kobenhavn, Denmark, February 26th, 1980.

\section{Introduction}

The East Greenland continental margin was separated by rifting and sea floor spreading from the NW European margin during the Early Tertiary (Talwani \& Eldholm, 1977) and prior to active spreading the two margins were part of a continuous semi-cratonic block. The zone of Early Tertiary rifting is in part coincident with the trend of the Caledonian orogeny. The post-Caledonian geological records on both margins contain evidence for repeated extension, crustal foundering and rifting since at least Early Permian times. In contrast to this, Lower Tertiary sea floor spreading was initiated and established in the whole NE Atlantic within a few million years.

The region has a long history of exploration and the general Mesozoic stratigraphy and facies have received considerable study. Tertiary sediments are less well known as they occur mainly as thin sequences just below, between and above plateau basalts of Paleocene age. A review of the late Palaeozoic and Mesozoic was given by Birkelund \& Perch-Nielsen (1976). Large-scale sedimentologic studies have been made on the Triassic (Clemmensen, 1978a, b, 1979, 1980), and on the Jurassic (Surlyk, 1977a, b, 1978a, b). Papers including some of the major conclusions given here have been presented by Surlyk et al. (in press) and Larsen (1979a, b).

The present account differs from the paper by Surlyk et al. (in press) by: (I) Dealing only cursorly with the Mesozoic geology and incorporating a brief review of the pre-Mesozoic geology, (II) including more data and discussions relevant to the offshore geology, (III) including a backwards rotation of the proposed ocean-to-continent transition through the total pole of opening and (IV) suggesting some minor revisions of the Tertiary spreading history within the NE-Atlantic 
and (V) including a short note on the petroleum geological aspects.

The East Greenland shelf remained almost unexplored for many years due to the prevailing harsh physical environment, and the proposed offshore extension of the Mesozoic basins (Johnson et al., 1975a; Henderson, 1976; Larsen \& Thorning, 1979; Larsen, unpublished) still require firm proof.

Evidence for the presence of extensive sedimentary basins on the shelf was given by $\mathrm{B}$. Larsen (1975), H. C. Larsen (1975) and Johnson et al. (1975a). Further evidence was presented by Featherstone et al. (1977) and more recently Hinz \& Schlüter $(1978,1979)$ presented an analysis of multi-channel seismic reflection data.

Considerable information is furthermore expected to be gained from the interpretation of a recent high sensitivity aeromagnetic survey of the shelf (Larsen \& Thorning, 1979, in press) and a planned regional multi-channel seismic reflection survey (Risum, in press).

\section{Pre-Tertiary geology}

\section{a. Crystalline basement}

Three major units of crystalline basement exist in East Greenland: Archaean ( $>2500$ m.y.), Proterozoic (2500-1000 m.y.), and Caledonian basement (520-375 m.y.), (fig. 1; Bridgwater et al., 1978; Higgins \& Phillips, 1979).

The Archaean basement is to a great extent dominated by more or less deformed plutonic rocks of various compositions, predominantly granitic to granodioritic. The metamorphic grade of the rocks is generally high amphibolite to granulite facies.

The Proterozoic complex on the southern tip of Greenland consists of Proterozoic supracrustal rocks and large granite complexes, whereas the Proterozoic complex in central South-East Greenland mainly consists of reworked and intensely sheared Archaean rocks. The major structures of South-East Greenland generally strike perpendicular to the trend of the coast line.

No major geological event between the Early to Middle Proterozoic and the uppermost Cretaceous - lower Tertiary is recorded within South-East Greenland. The existence of a longlived stable cratonic area including SE Green- land and Rockall-Hatton Bank before the rifting and drifting associated with the northward extension of the Atlantic Ocean seem likely, and is in contrast to the much more complex geological record found on both sides of the North Atlantic to the north of the Faeroe-Iceland-Greenland Ridge. Here both the NW European margin and the East Greenland margin is dominated by the Caledonian folding and metamorphism followed by Palaeozoic molasse sedimentation and Mesozoic rifting. The isotopic data allow the recognition of orogenic phases in North-East Greenland of Archaean (2500 m.y.), Hudsonian (1800-1700 m.y.), Grenvillian (1200-1000 m.y.) and Caledonian (520-375 m.y.) age (Higgins \& Phillips, 1979). The Caledonian fold belt therefore comprises supracrustals, gneisses and plutonic rocks of very different age and origin including non-metamorphic to intermediate metamorphic clastic and carbonate sediments of late Precambrian to Ordovician age (Haller, 1970).

\section{b. Devonian to Carboniferous molasse sedimentation}

The Caledonian orogeny in East Greenland was followed by sedimentation of Middle and Upper Devonian and Upper Carboniferous continental clastics in intramontane basins, forming sequences exceeding $12 \mathrm{~km}$ in stratigraphical thickness (Bütler, 1959, 1961; Haller, 1970). In the Devonian, volcanism, folding and in part thrusting, occurred. A progressive denudation of the upfolded Caledonian mountain range and associated molasse sedimentation thus seems to prevail up to at least Upper Carboniferous time. The Devonian volcanism was dominated by acid intrusives and extrusives with subordinate occurrence of basaltic extrusives. It is of considerable interest to note that small amounts of hydrocarbons (Secher et al., 1976) have been reported within both the Devonian and Carboniferous volcanics and clastics.

\section{c. Permian faulting and transgression}

Conglomerates and arkoses of Early Permian age are occasionally exposed between $70^{\circ}$ and $72^{\circ} \mathrm{N}$ in a narrow NNE-SSW striking zone. The deposition seems to have taken place in grabens or half-grabens with synsedimentary tectonic activity (Kempter, 1961; Haller, 1970; Collinson, 1972). The Permian tectonic activity can be 
traced to $75^{\circ} \mathrm{N}$ where, in several places, Carboniferous rocks are downfaulted into small grabens (Vischer, 1943; Maync, 1949; Haller, 1970). The fault systems, initiated during Late Carboniferous and Permian times, form a NNE-SSW trending major fault named the postDevonian Main Fault (Vischer, 1943) which in most places delineates the westwards extension of post-Devonian rocks. With a parallelism to the Fenno-Scandian Border Zone (Ziegler, 1978), this fault has since acted as a dividing line between a stable block to the west, which only occasionally and to a minor extent has been transgressed, and an eastern area which has suffered continuous crustal foundering and faulting associated with accumulation of Mesozoic continental and marine sediments.

The early Permian continental regime was followed by a major transgression in the Late Permian which even covered the marginal parts of the western stable block.

The Upper Permian marine to nearshore deposits show a marked unconformity and are present between $71^{\circ}$ and $75^{\circ} \mathrm{N}$ in East Greenland (Birkelund \& Perch-Nielsen, 1976). The deposits include a basal conglomerate, limestone banks and reefs, anhydrite and gypsum, dark shales formed in lagoons and the Upper Permian is occasionally sealed by red sandstone or sandy limestone. The presence of a more advanced evaporite sequence including halite within the present day shelf area cannot be excluded.

\section{d. Mesozoic rift sedimentation and faulting}

Fundamental to the Mesozoic evolution is the continuous progressive fragmention of the margin east of the post-Devonian main fault into a half-graben structure running NNE-SSW from about Scoresbysund $\left(70^{\circ} \mathrm{N}\right)$ and northwards to at least $76^{\circ} \mathrm{N}$ (Surlyk, 1978b; Surlyk et al., in press).

Continental facies and a transverse infill of the faultbounded trough prevailed during the Triassic (Clemmensen, 1980).

A northward transgression of the rift was initiated during the Lower Jurassic and was completed at the end of the Jurassic (Surlyk, 1978 a, b Surlyk et al., in press).

The Cretaceous of East Greenland is generally poorly preserved but seems to reflect further transgression with a possible maximum at
Cenomanian time. In accordance with this, sediments, of Late Cretaceous age are found as far south as Kangerdlugssuaq (fig. 1) far outside the main outcrop area for the Mesozoic (Soper et al., 1976).

The major Mesozoic tectonic phases took place in the early and late Triassic, Rhaetian, Pliensbachain, Bajocain, Bathonian, late Oxfordian, Kimmeridgian, mid Volgian-Valanginian, Aptian-Albian and Turonian and correlates well with NW Europe (Surlyk et al., in press; Ziegler, 1978). The Jurassic, and especially the Late Jurassic to Early Cretaceous tectonism changed the incipient rift into a half-graben structure with a system of westward tilted fault blocks (Vischer, 1943; Surlyk, 1978 a). An equivalent prevalence of westward tilted blocks is found on the Norwegian shelf (Møre to Lofoten-Vesterålen area, Jørgensen and Navrestad, 1979, Eldholm et al., 1979) which implies that the asymmetry found in East Greenland can hardly be explained by a marginal position within a symmetrically developed major rift.

\section{Onshore Tertiary - a record of continental break-up}

The Mesozoic rift tectonism was probably not related to mantle-upwelling and never led to active plate separation by sea floor spreading. The Tertiary of East Greenland records the initiation of the final break-up of the NE Atlantic (Brooks, 1973; Soper et al., 1976; Talwani \& Eldholm, 1977) and the subsequent formation of a passive margin. The early stages of plate separation can be best exemplified onshore, whereas evidence for the subsequent subsidence and sedimentation is almost exclusively confined to the shelf.

\section{a. Pre-volcanic sedimentation}

The present day occurrences of pre-volcanic Tertiary sedimentary deposits are restricted to scattered localities protected against erosion by basalts (fig. 1) and a more continuous cover has probably originally existed. However, the westerly pinching out of the sediments below the basalts, the occurrence of both shallow marine and terrestrial facies and the proximity of a western sediment source indicates that the deposits approximately mark the western limit of the 
Early Tertiary sea (Vischer, 1943; Soper et al., 1976).

The sediments occur in two different areas (fig. 1). Within the northern area thin terrestrial deposits including alluvial fan conglomerates and fluvio-lacustrine sandstones occur widespread in the Wollaston Forland and Clavering $\varnothing$ area just below the basalts (Vischer, 1943). They are derived from a western source area. To the east, shallow marine deposits below basalts have been reported from Lille Pendulum (Maync, 1949).

The southern area comprises two localities with marine deposits. At Kap Gustav Holm (fig. 1), fossiliferous conglomeratic sandstones, finegrained sandstones and mudstones form an approximately $30 \mathrm{~m}$ thick marine to shallow water sequence resting on basement and covered with lavas (Wager, 1934). A few thin submarine lavas within the sediments point to a subaqueous mode of eruption during the incipient volcanism. The unit was later severely dissected by dykes and tilted seawards up to $50^{\circ}$ (Wager, 1934). Wager furthermore suggested that the Kap Gustav Holm sediments are of Tertiary or slightly older age.

The Kangerdlugssuaq area (fig. 1) comprises a sedimentary record ranging in age from Lower Albian to Danian. The succession most likely rests on Precambrian basement (Wager, 1934, 1947) and is overlain by basaltic extrusive rocks probably of the order of $6-7 \mathrm{~km}$ in stratigraphic thickness. The sedimentation seems continuous through the Cretaceous-Tertiary boundary but the incoming of more frequent coarse clastic and the occurrence of plant floras in the Danian sediments point to shallowing marine conditions (Soper et al., 1976). The overlying, mainly volcanogenic sequence starts unconformably with up to $20 \mathrm{~m}$ of sediments comprising a basal conglomeratic horizon passing into coarse sandstones and volcanogenic sediments. They are followed by hyaloclastic breccias with pillow lavas and intercalated tuffs and black shales of Late Paleocene age (Sparnacian).

\section{b. Late Paleocene volcanism}

Distribution and mode of occurrence. The pre-basaltic volcanogenic sediments occurring at Kap Gustav Holm, Kangerdlugssuaq and Lille Pendulum (Wager, 1934; Maync, 1949; Soper et al., 1976) heralded a period of excessive effusive volcanism along the East Greenland margin related to the early stages of separation of Greenland from NW Europe by sea floor spreading (Brooks, 1973; Soper et al., 1976). Present day remnants of this volcanism occur onshore between latitudes $66^{\circ}$ and $75^{\circ} \mathrm{N}$ in the form of extensive sheets of plateau basalts of various thicknesses (Fig. 1). Apart from the lower and uppermost part of the sequence, volcanism was almost exclusively subaerial as a volcanic landmass rapidly formed (Brooks et al., 1976; Soper et al., 1976; Soper \& Costa, 1976).

The Kangerdlugssuaq locality contains scarce but unambiguous evidence for an east to west direction of flow of the lower lavas placing the volcanic source within the present day shelf area (Wager, 1934; Soper et al., 1976). Variations in thickness of the lava pile due to both erosion and initial differences occur throughout the province. A general landwards decrease in thickness of the lava sequence and in the average thickness of flows has been reported from the Kangerdlugssuaq area by Brooks (1973) and seems valid for the northern part of the Blosseville coast as well (W. S. Watt, personal communication, 1979), but in addition, marked lateral variations occur along the coast. Stratigraphic thickness is estimated at $6-7 \mathrm{~km}$ in the Kangerdlugssuaq area (Wager, 1947). Thickness of the lava sequence is estimated at a minimum of $1200 \mathrm{~m}$ and around $2000 \mathrm{~m}$ immediately to the south of Scoresby Sund (Birkenmajer, 1972; Watt et al., 1972), while in the Gauss Halvø and Wollaston Forland area the total thickness probably did not exceed about $1000 \mathrm{~m}$ (Vischer, 1943; Hald, 1978). The initial differences in thickness most likely depends on the proximity and the productivity of

Fig. 1. Schematic map of the East Greenland Margin showing major tectonic units, post-Palaeozoic outcrops and distribution of sediments (Tertiary) offshore. Western boundary of offshore sediments not drawn to the north of $72^{\circ} \mathrm{N}$ as onshore and offshore sediments merge. Estimated maximum thickness of sediments given in kilometres. Basement on shelf mainly Precambrian metamorphic rocks and Tertiary volcanics. Oceanic magnetic anomalies and magnetic lineaments on shelf from Talwani \& Eldholm (1977) and own observations. Bathymetry from unpublished compilation by $H$. C. Larsen.

GFZ: Greenland Fracture Zone; JMFZ: Jan Mayen Fracture Zone; KR: Kolbeinsey Ridge; DSR: Denmark Strait Ridge; ER: Erik Ridge; KFa: Kap Farvel; Kap Gustav Holm: KQ: Kangerdlugssuaq; S: Savoia Halvø; SS: Scoresby Sund; J: Jameson Land; L: Liverpool Land. 


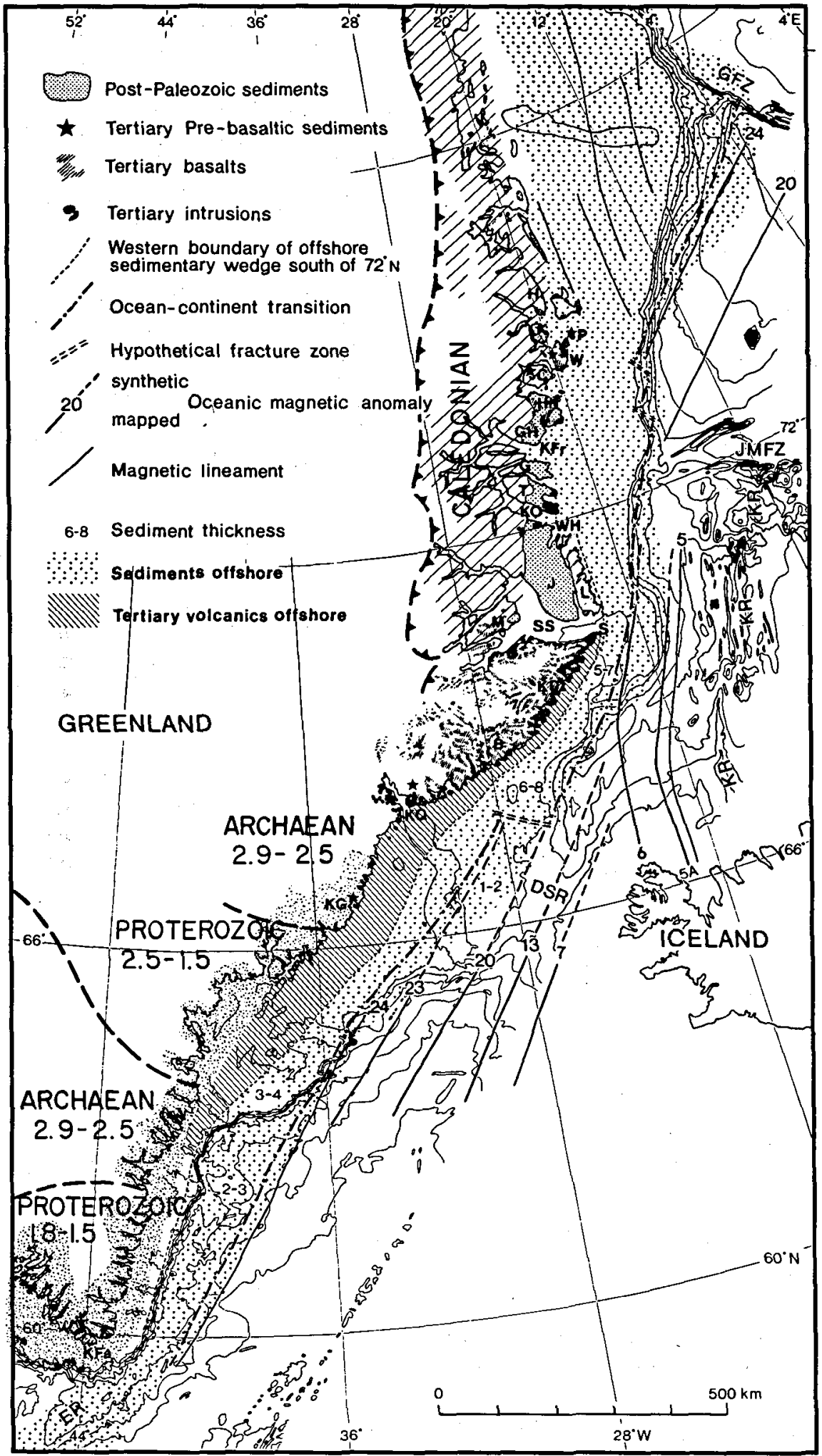


the volcanic source, but also on the existence of sub-basaltic relief of partly tectonic origin (Vischer, 1943; Wenk, 1961; Noe-Nygaard, 1976).

Stratigraphy and chemistry. No regional stratigraphy within the early Tertiary basalts has yet been established. The overall trend within the sequence is a monotonous pile of aphyric or plagioclase bearing flows typically $10-30 \mathrm{~m}$ thick (extremes about $1-50 \mathrm{~m}$ ) and with a clearly tholeiitic trend (Noe-Nygaard \& Pedersen, 1974; Brooks et al., 1976). Pyroclastics and interbedded sediments of insignificant thickness occur locally, especially to the south of Scoresby Sund. The monotony of the lava pile is interrupted by picritic flows within the lowermost part and alkaline lavas in the uppermost part (Katz, 1952; Anwar, 1955; Haller, 1956; Brooks \& Rucklidge, 1974; Brooks et al., 1976, 1979). The highly undersaturated lavas may have been widespread; but are only found in situ in the Nunatak region and as pebbles within the postbasaltic Kap Dalton sediments and erratics (Wager, 1935).

The fluvio-lacustrine interbedded sediments are generally $0.5-2 \mathrm{~m}$ in thickness with occasional occurrences of coal and fossilized wood. Together with the overlying shallow marine sediments of Lower Eocene age they reveal that subsidence kept almost pace with the supply of volcanics and that the eruption of the immense lava pile took place within a few million years in the Upper Paleocene (Brooks, 1973; Soper et al,, 1976; Soper \& Costa, 1976).

\section{c. Post-basaltic intrusives and tectonism}

Intrusion of a dyke swarm. A coast parallel dyke swarm was intruded into the Precambrian basement and the overlying lavas between $66^{\circ} 15^{\prime}$ and $69^{\circ} 45^{\prime} \mathrm{N}$ at the very end of the effusive period (Wager \& Deer, 1938; Nielsen, 1975; Myers, in press). The dyke swarm continues offshore in a broad belt southwards to at least $63^{\circ} \mathrm{N}$ (Larsen, 1978). Although still debated (Faller \& Soper, 1979), the major part of the dyke swarm most likely pre-dates the formation of seawards tilted fault-blocks and shows a tholeiitic trend very similar to the plateau basalts (Nielsen, 1978).

The combined onshore and offshore extension of the dyke swarm shows that considerable crustal dilation occurred and marks the change from the simple surface outpouring of mantle derived magma to initial plate separation. Larsen (1978) accordingly assigned an anomaly 24 age (55-56 m.y., LaBrecque et al., 1976) for the major tholeiitic part of the swarm in agreement with the suggested reverse magnetization of the lavas (Faller, 1975).

Post-basaltic tectonics. The strong seawards tilting of fault-blocks between $66^{\circ} 30^{\prime}$ and $70^{\circ} \mathrm{N}$ (up to $40-50^{\circ}$ ) was interpreted by Wager \& Deer (1938) as a coastal monoclinal flexure formed prior to implacement of the dyke swarm in its upper arch, an interpretation adapted by Faller and Soper (1979) in their presentation of palaeomagnetic data from the region. Nielsen (1975, 1978), Larsen (1978) and Myers (in press) all favours a post-intrusive formation of this coastal feature invoking faulting and seawards rotation of fault-blocks. In agreement with the latter suggestion the down flexuring of crystalline basement below thick accumulations of post-basaltic sediments occurs considerably seawards of the coast (fig. 1 and B. Larsen, in press).

In the northern area post-basaltic tectonism was mainly confined to a considerable reactivation (throw 500-1000 m) of the former Mesozoic normal faults (Hald, 1979) but slight seawards tilting of the lavas is also reported from a single locality in Wollaston Forland (Vischer, 1943).

The presence of extensive sills in the basalt free area between Scoresby Sund and Kejser Franz Josephs Fjord allows the recognition of Tertiary tectonism. As in the northern basalt province, reactivation of Mesozoic normal faults prevailed, but reverse faulting is also reported (Haller, 1970).

An important exception to the seawards tilting of fault-blocks occurs at Savoia Halvø (fig. 1) where activation of post-basaltic normal faults of inferred Upper Oligocene to Lower Miocene age led to the formation of landwards tilted fault-blocks within small grabens (Wager, 1935; Birkenmajer, 1972; Watt, 1975). At the time of faulting the incipient Kolbeinsey Ridge was situated only about $50 \mathrm{~km}$ to the east.

The seawards tilting of fault-blocks thus reflects cessation of mantle derived volcanism and associated crustal dilation and the more restricted and later landwards tilting of blocks relates to renewed spreading close to the coast. 
In addition to the tilting of fault blocks and the reactivation of normal faults considerable and differentiated vertical movements took place throughout the East Greenland continental margin area during the Tertiary. The coastal area was as a whole uplifted $1.5-2.5 \mathrm{~km}$ to its present position and local doming with an amplitude of about $6 \mathrm{~km}$ occurred around Kangerdlugssuaq (Brooks, 1979). Doming and regional uplift was most likely initiated during the OligoceneMiocene (Brooks, 1979, and this paper) and within the same time, subsidence in the range of 3-6 km occurred offshore.

Tertiary plutonism. The Early Tertiary effusive volcanic episode in East Greenland was followed by intrusion of a suite of plutonic rocks (fig. 1) (Deer, 1976) ranging in age from about 55 m.y. for the Skaergaard intrusion (Brooks \& Gleadow, 1977) to about $30 \mathrm{~m} . \mathrm{y}$. for the Werner Bjerge intrusive center (Rex et al., 1979). Pre- and in part syn-tectonic tholeiitic gabbros predominate the interval from 55 to 50 m.y. and are followed by post-tectonic mainly syenitic intrusions (Wager, 1947; Deer, 1976; Noe-Nygaard, 1976; T. F. D. Nielsen, personal communication, 1979; Myers, in press).

The plutonic activity was mainly confined to the coastal area (fig. 1). Intrusions positioned far inland are, however, found around Kangerdlugssuaq and Kong Oscars Fjord.

\section{d. Post-basaltic sedimentation}

Post-basaltic Tertiary sediments are only known from East Greenland in two closely lying localities (Wager, 1935; Hassan, 1953; Birkenmajer, 1972; Soper \& Costa, 1976). These sediments are of particular interest as they can be dated biostratigraphically, and thus provide a younger limit for the effusive volcanism. They are furthermore the only onshore exposures related to the major sedimentary wedge situated offshore (Hinz \& Schlüter, 1978).

Marine sediments of Eocene and Oligocene age occur at Kap Dalton (fig. 1) and at the Savoia Halvø (fig. 1). Marine sediments of inferred Miocene age also occur at the Savoia Halvø.

The Eocene-Oligocene sequence can be divided into two units each $40-50 \mathrm{~m}$ thick. The lower unit comprises $2 \mathrm{~m}$ of basal conglomerate overlain by about $30 \mathrm{~m}$ of shell-bearing and in part calcareous sandstone followed by a thin calcareous mudstone. Volcanic detritus occurs throughout the lower unit and comprises pebbles of highly alkaline composition very different from the surrounding volcanics (Wager, 1935).

The upper unit commences with a 25 m thick, in part coarse-grained sandstone comprising detritus from the pre-volcanic metamorphic complex (Wager, 1935). The sandstone passes up into more fine-grained siltstone and shale. A hiatus may exist between the two lower units as a Lower Eocene (Ypresian) age is obtained from the lower unit and an Oligocene age for the upper unit (Hassan, 1953; Birkenmajer, 1972; Soper \& Costa, 1976) and is further supported by the incoming of basement detritus indicating considerable denudation of the source area.

The Miocene sequence at Savoia Halvø comprises a basal formation, showing a lateral facies change from fan breccias into conglomerates. It is overlain by $40 \mathrm{~m}$ thick shallow marine fossiliferous sediments (Hassan 1953; Birkenmajer, 1972).

Both the formations at Kap Dalton and at Savoia Halvø rest directly and probably conformably, on lavas and their present day occurrence is due to their position on down-faulted and westward tilted fault-blocks. The throw on the border faults is up to about $1500 \mathrm{~m}$.

According to Birkenmajer (1972) the initiation of normal faults and associated small grabens took place between the Eocene-Oligocene and the Miocene and the basal breccia of the Miocene sequence was probably formed along a fault scarp. The age of this tectonic phase is in good agreement with the suggested stratigraphy within the offshore sedimentary wedge (Hinz \& Schlüter, 1978, 1979) and is most easily explained as related to incipient spreading along the nearby Kolbeinsey Ridge.

\section{Offshore geology}

\section{a. Regional setting of the shelf}

The East Greenland shelf is bounded landwards by continental crust with an Archaean to Middle Tertiary geologic record and seawards by oceanic crust of Early to Middle Tertiary age and constitutes a passive, mainly rifted type margin (fig. 1) (Talwani \& Eldholm, 1977). 


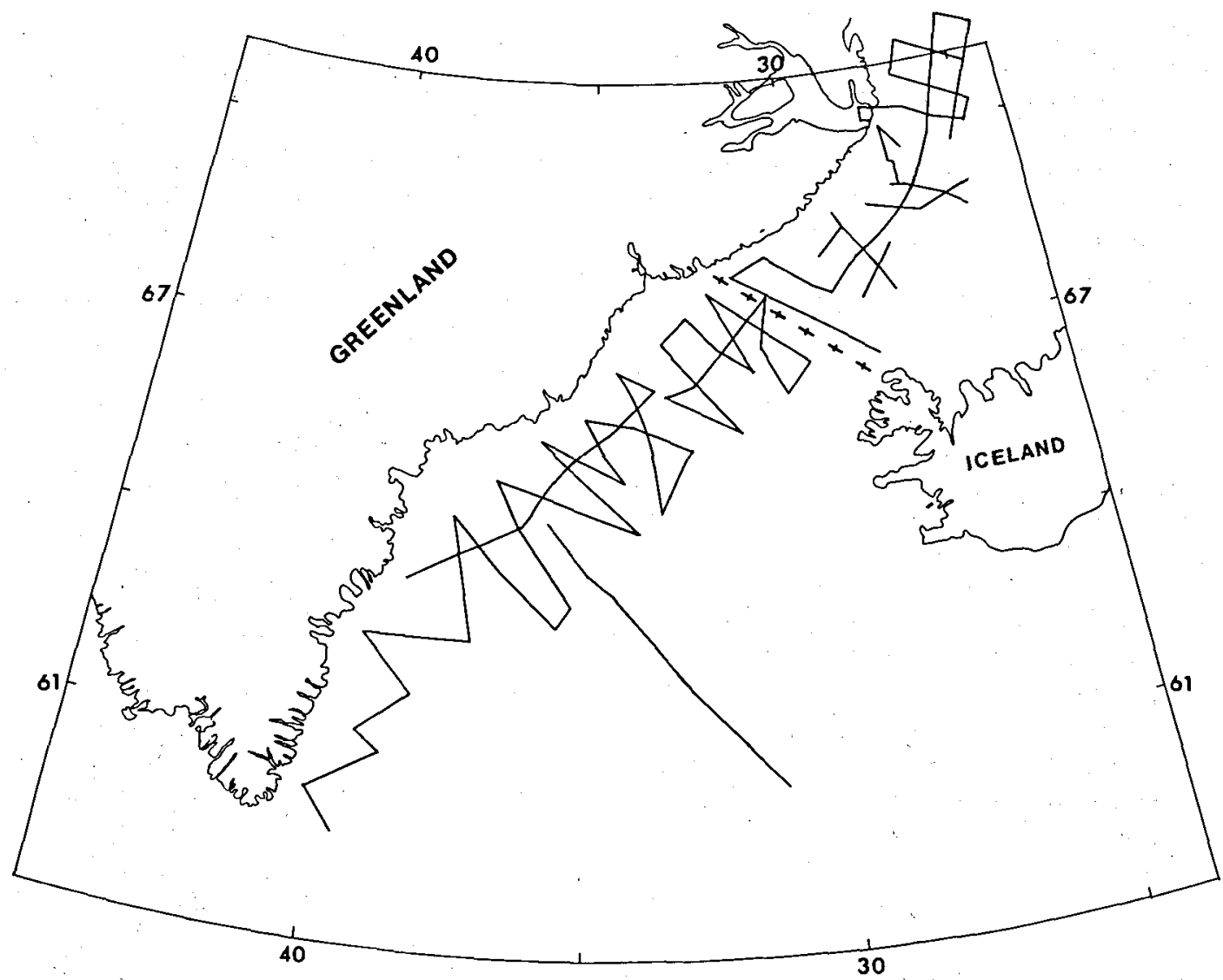

Fig. 2. Tracks of multi-channel seismic reflection data used in this paper. CNEXO lines to the south of line between Iceland and Greeniand, BGR lines to the north. See text for references.

The margin can be divided into two areas with considerably different geologic histories. Within the southern area, stable cratonic conditions prevailed from the Middle Proterozoic to about Upper Cretaceous (Wager, 1934, 1947; Bridgwater et al., 1978) where rifting associated with the subsequent early Tertiary continental break-up is assumed to start. Within the northern area, the complex geologic record shows evidence for plate separation and suturing of Middle Proterozoic, Grenvillian and Caledonian àge (Higgins \& Phillips, 1979) followed by prolonged rifting and crustal foundering throughout the Late Palaeozoic and Mesozoic (Birkelund \& Perch-Nielsen, 1976).

Separation of the Greenland plate from NW Europe was initiated by sea floor spreading and continental dilation at the Paleocene-Eocene boundary (anomaly 24, Talwani \& Eldholm; 1977; Soper et al., 1976; Larsen, 1978). Sea floor spreading was established within the whole NE
Atlantic prior to anomaly 23 along the Reykjanes Ridge, the Aegir Ridge and the Mohns Ridge. Cessation of spreading along the Aegir Ridge at anomaly 7 time (Oligocene) and subsequent initiation of spreading not later than anomaly 6 (fig. 6 and Vogt et al., 1980) along the Kolbeinsey Ridge led to the separation of the Jan Mayen. Ridge from the East Greenland Margin (Talwani \& Udintsev, 1976; Talwani \& Eldholm, 1977) accompanied by renewed tectonism on the Greenland shelf and coast.

b. Morphology and surface lithology

Morphology. The regional morphology of the shelf and adjacent deep water areas is shown in fig. 1. A sequence of regional structures is clearly identified. They comprise from north to south: Greenland Fracture Zone (GFZ), Jan Mayen Fracture Zone (JMFZ), Kolbeinsey Ridge (KR), Denmark Strait Ridge (DSR), and in the extreme south, Erik Ridge (ER). An unnamed prominent 
high occurs just north of JMFZ with a strike clearly different from that of JMFZ ruling out a simple common origin.

A three-fold division of the shelf can be made as follows: (1) A northern area $\left(72^{\circ}-78^{\circ} \mathrm{N}\right)$ in which the shelf broadens to the north from 125 $\mathrm{km}$ to $300 \mathrm{~km}$, and possesses a well-defined linear shelf break and rather normal dip of the slope and rise. (2) A middle area $\left(64^{\circ}-72^{\circ} \mathrm{N}\right)$ with a lobated shelf edge and large variations in shelf width. Dip of slope is generally low and in the Denmark Strait the shelf edge almost vanishes. (3) A southern area $\left(59^{\circ}-64^{\circ} \mathrm{N}\right)$ with a narrow shelf, a sharp shelf edge with a linear trend and a steep slope. Surface morphology of this southern area seems rough compared to the two northern areas and deep intersecting transverse troughs related to the fjords seems more frequent and associated with submarine highs on the slope and rise (fig. 1).

A structural control of the shelf edge is suggested for the northern and southern linear segments, and strong progradation is expected to have affected the position of the shelf edge within the middle part as it is seen off the mouth of Scoresby Sund.

Surface lithology. The map in fig. 1 shows the distribution of pre-Quaternary sediments, Tertiary volcanics and Precambrian basement. South of $72^{\circ} \mathrm{N}$ the map base is controlled by single and multi-channel seismic reflection data (fig. 2 and B. Larsen, 1975, Featherstone et al., 1977, Hinz \& Schlüter, 1978, 1979; and unpublished data from Centre National pour l'Exploitation des Oceans (CNEXO)), seismic refraction data (Johnson et al., 1975a; Grønlie \& Talwani, 1978), aeromagnetic data (fig. 3 and H. C. Larsen, 1975; Larsen \& Thorning, 1979) and morphology (Sommerhoff, 1973). To the north the map is based on extrapolation from the onshore configuration of sediments and a tentative interpretation of available aeromagnetic data (Johnson et al., 1975a; Larsen \& Thorning, 1979).

From $59^{\circ}$ to $64^{\circ} \mathrm{N}$ only a small rim of sediments is present on the outermost part of the shelf (fig. 1). A considerable areal increase of sediment cover is associated with the widening of the shelf at $64^{\circ} \mathrm{N}$. The boundary between basement and sediment cover has a coast parallel trend from the

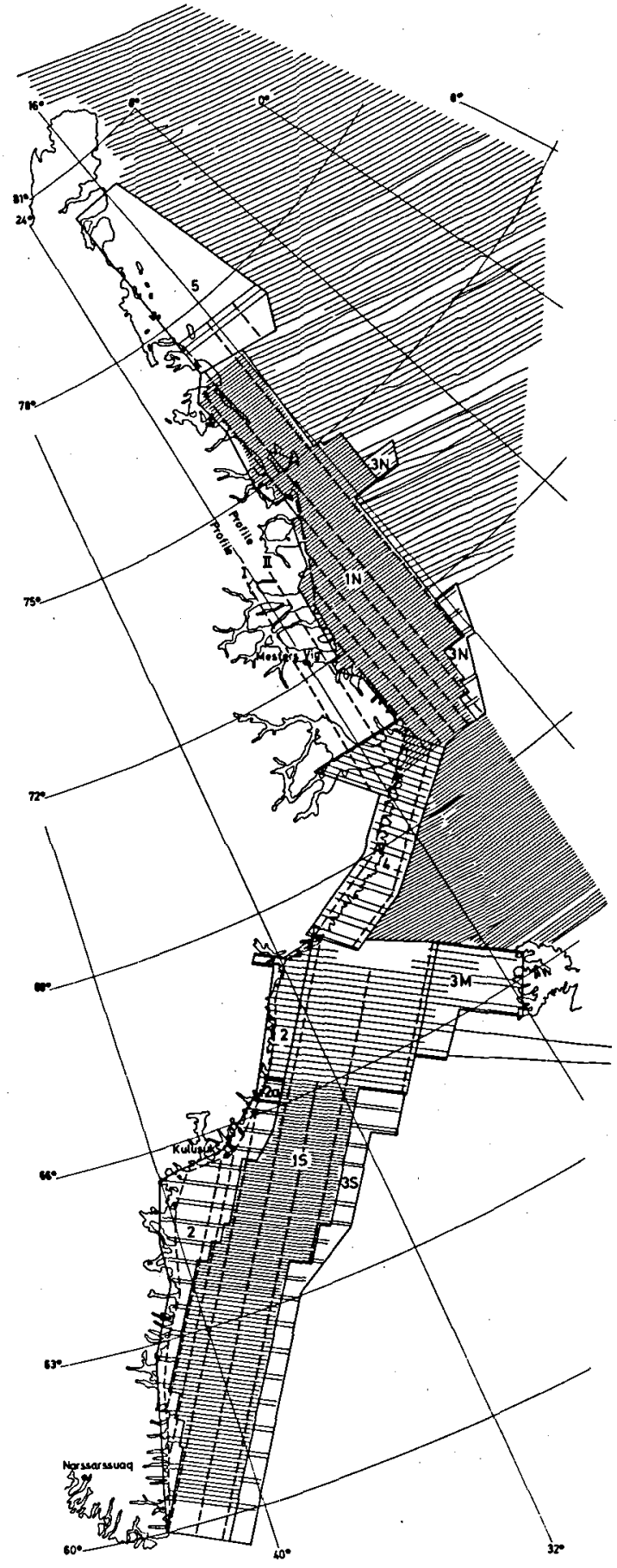

Fig. 3. Aeromagnetic coverage of the East Greenland margin (only low-altitude, total field data shown). Some additional lines (not shown) exist between $63^{\circ} \mathrm{N}$ and $66^{\circ} \mathrm{N}(H . C$. Larsen, 1975 and H. C. Larsen, 1978). New high-sensitivity data (Larsen and Thorning, 1979, in press) within the blocks labelled 1 S to 5, data outside the blocks from U.S. Naval Oceanographic Office $\left(66^{\circ} \mathrm{N}\right.$ to $\left.70^{\circ} \mathrm{N}\right)$ and U.S. Naval Research Laboratory $\left(72^{\circ} \mathrm{N}\right.$ to $\left.83^{\circ} \mathrm{N}\right)$. See text for references. 


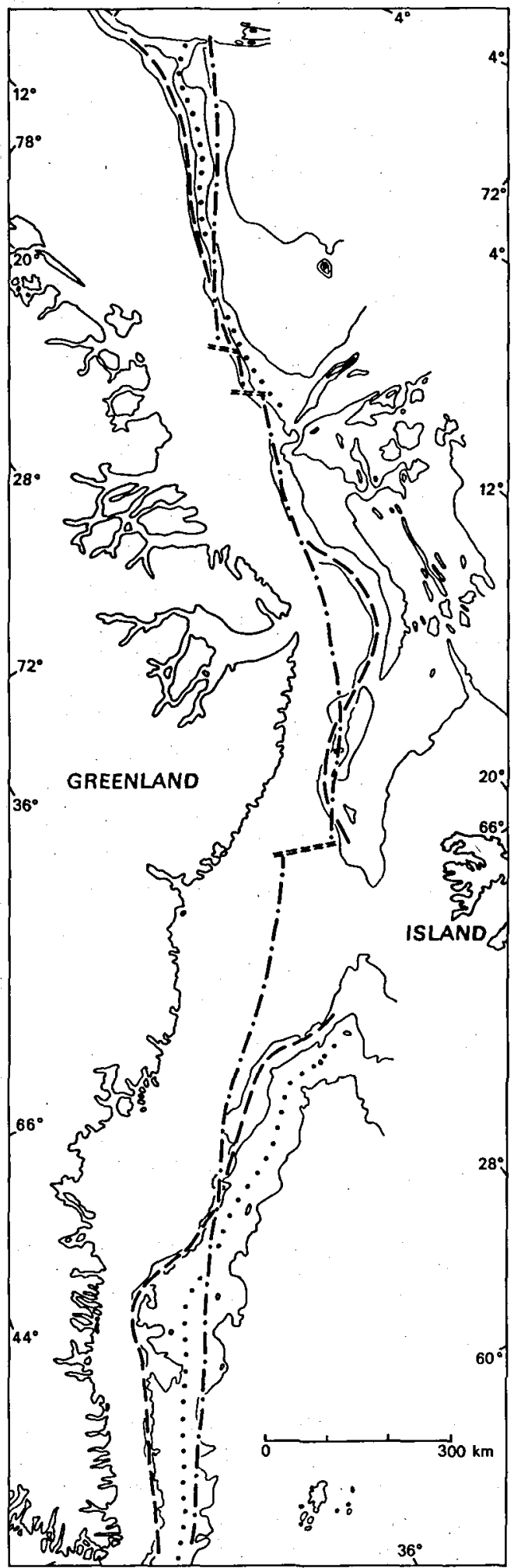

extreme south to about $66^{\circ} \mathrm{N}$ from where it tends to approach the coast. Between approximately $63^{\circ}$ and $70^{\circ} \mathrm{N}$, the offshore sedimentary sequence is separated from the western Precambrian and younger onshore rocks by a zone of Early Tertiary lavas and/or a zone intensely injected by dykes of similar age (Larsen, 1978). The zone of offshore volcanics may probably be extended further north when new data become available.

The sedimentary wedge offshore East Greenland overlaps seawards onto oceanic crust of Tertiary age (fig. 1).

\section{c. Ocean to continent transition}

The ocean to continent transition (OCT) constitutes a boundary of first order of wide scientific and petroleum geological importance: Some suggestions for the OCT offshore East Greenland are included in the various pre-drift models proposed for the NE Atlantic. The fits proposed by Bullard et al. (1965) and Le Pichon et al. (1977) invoke an OCT related to a certain water depth (fig. 4), the Bott \& Watts fit (1971) incorporated geologic information and the Talwani \& Eldholm fit (1977) mainly relies on fit of identified oceanic anomalies. More specific attempts to define an OCT for segments of the shelf were made by Featherstone et al. (1977), Eldholm \& Windisch (1974) and. Hinz \& Schlüter (1979). Their suggestions are followed in the present account together with an interpretation of the available aeromagnetic data.

The margin is here divided into 5 segments, each with an assumed uniform break-up history. The division comprises from north to south: (1) GFZ to JMFZ, (2) JMFZ to about $69^{\circ} \mathrm{N}$, (3) $69^{\circ} \mathrm{N}$ to northern boundary of DSR, (4) northern boundary of DSR to about $64^{\circ} \mathrm{N}$, and (5) $64^{\circ}$ to $60^{\circ} \mathrm{N}$.

The OCT within segment 1 had been defined as the interference zone between prominent $\mathrm{N}-\mathrm{S}$ striking anomalies on the shelf and oceanic anomalies (fig. 5). Progressive southward disappearance of anomaly 24 to 21 against the OCT points to repeated westward displacement of the

Fig. 4. Position of the ocean to continent transition $(O C T)$ as suggested by various authors. Dotted line from Le Pichon et al. (1977), dashed line from Bullard et al. (1965) and dashed/dotted line from this paper. Bathymetry ( $800 \mathrm{~m}$ 's equidistance) from unpublished compilation by $H$. C. Larsen. 


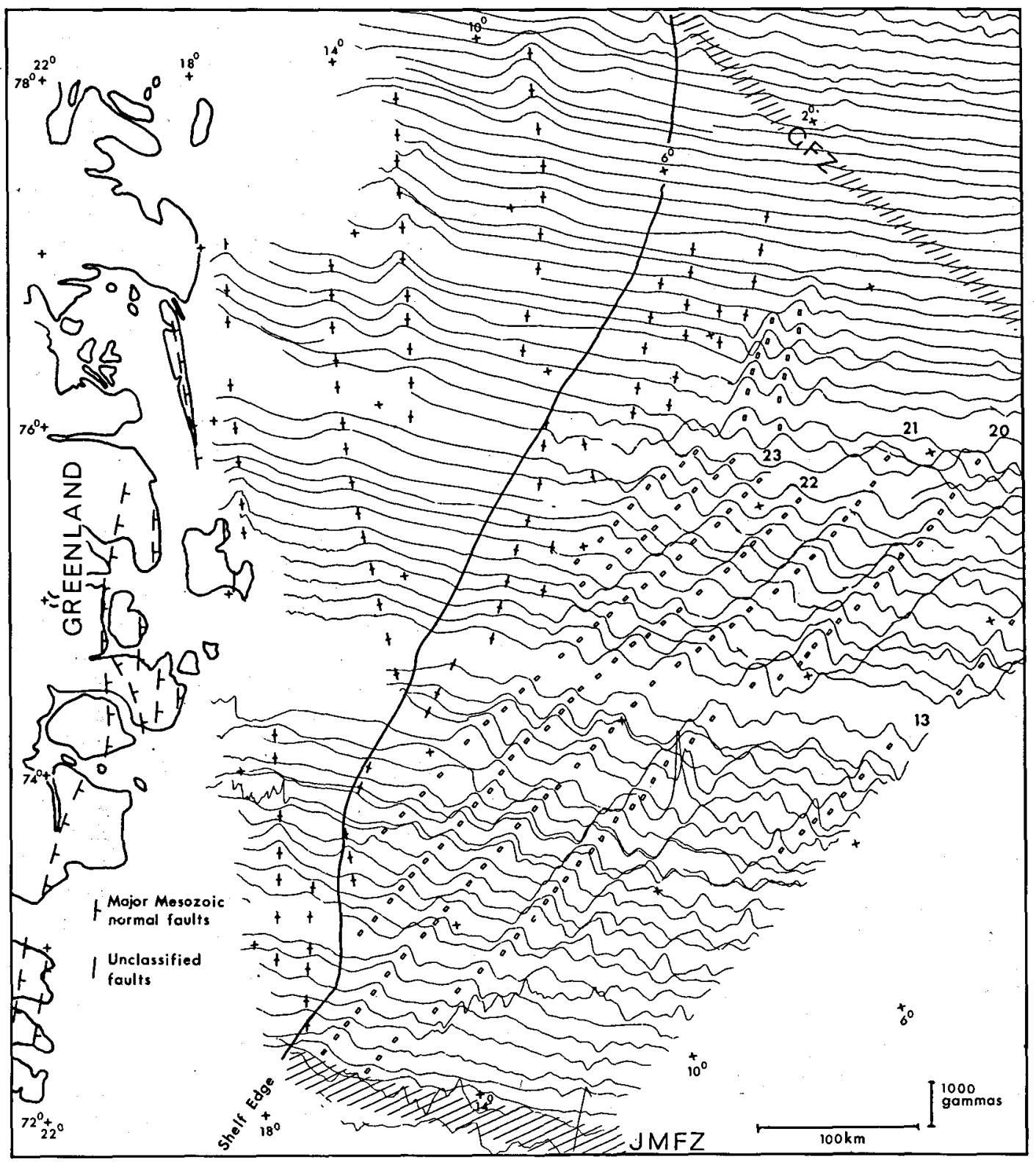

Fig. 5. Low-altitude aeromagnetic data collected by U.S. Naval Research Laboratory (ref. in text). Note the prominent differences in strike between the oceanic anomalies and the prominent magnetic lineaments on the shelf and slope. The most landwards occurring lineaments on shelf are clearly related to onshore Mesozoic normal faults (Surlyk, 1977b), which supports Johnson's view (1975a) of Mesozoic fault tectonics as responsible for the magnetic grain further offshore. The ocean to continent transitions are situated where the two different sets of magnetic lineaments meets.

GFZ: Greenland Fracture Zone. JMFZ: Jan Mayen Fracture Zone. Dating of oceanic anomalies partly from Grønlie and Talwani (1978).

southernmost early Mohns Ridge (fig. 5 and Hagevang et al., 1979).

The recognition of sea floor spreading along the Kolbeinsey Ridge prior to anomaly 5 (fig. 6 and Vogt et al., 1980) implies a more landward position of the OCT within segment 2 than hitherto accepted, but direct drawing of the boundary on the basis of aeromagnetic data is not possible due to very low amplitude character of the pre-anomaly 5 sequence. However, a linea- 


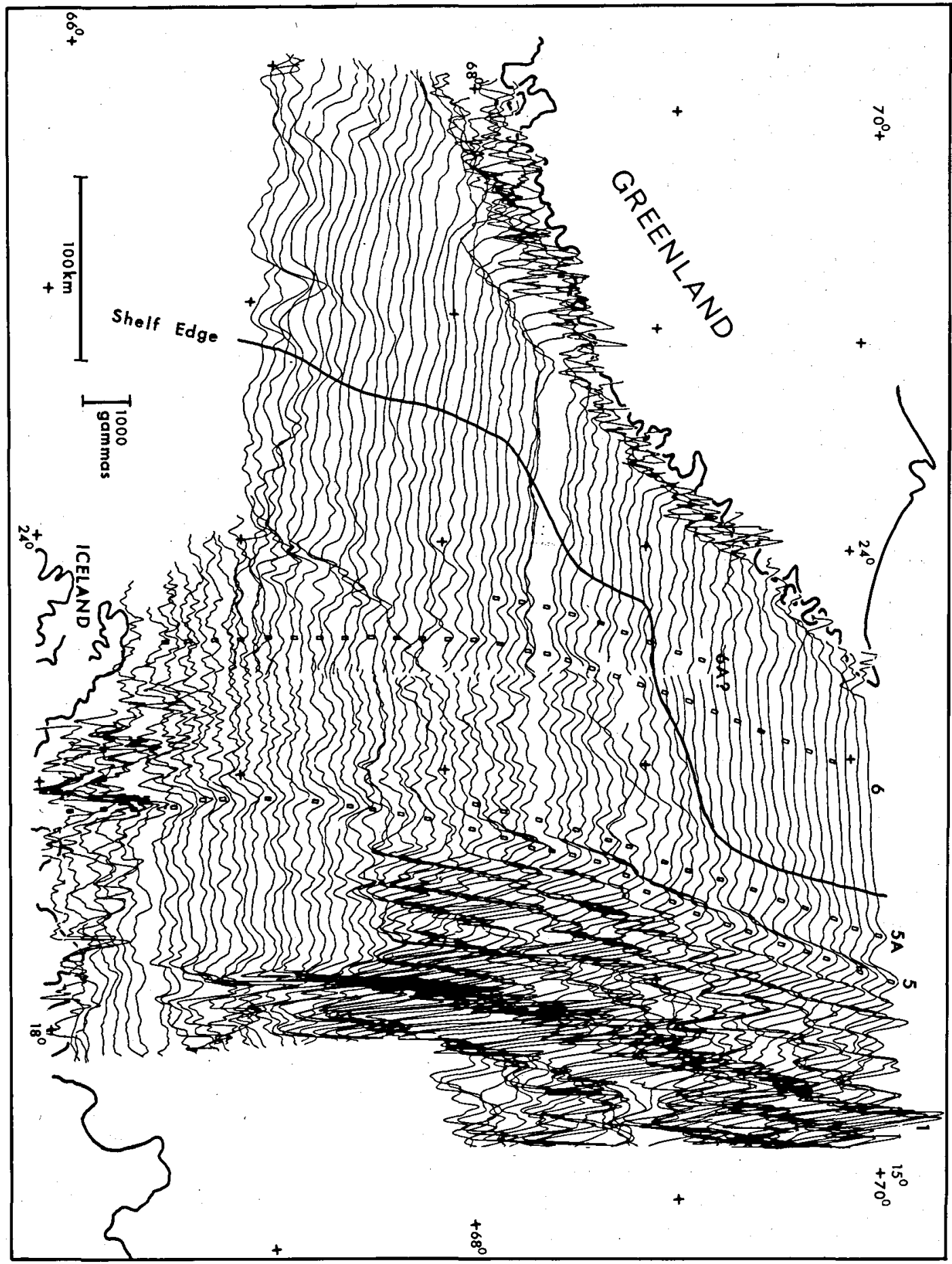

Fig. 6. Low-altitude aeromagnetic data collected by U.S. Naval Oceanographic Office (ref. in text), and showing the pre-anomaly 5 sequence suggested to exist (this paper and Vogt et al. 1980). Dating of anomaly 6 only tentative, but fits with the data presented by Vogt et al. 1980. The central magnetic smooth zone reveals the existence of a thick (Tertiary) sedimentary wedge (Johnson et al. 1975a, Hinz \& Schlüter 1979 and this paper), the narrow high frequency zone along the coast reveals the surface near presence of basalts and dykes (Larsen 1978 and this paper). The ocean to continent transition has been placed slightly landwards of anomaly 6 (following part of $6 A$ ) down to $69^{\circ} \mathrm{N}$ from where it runs roughly in the middle between the shelf edge and anomaly 6 (see text and fig. 4, 12). Westward displacement of the $O C T$ is suggested to take place at about $67^{\circ} \mathrm{N}$ (see also text). 
ment tentatively dated as anomaly 6 is safely identified and the OCT is drawn slightly landwards of this lineament.

Segment 3 seems continuous with segment 2 and also faces towards the Kolbeinsey Ridge. Drawing of an OCT in segment 3 slightly landwards of the assumed anomaly 6 implies, however, a position far seawards of the shelf edge which is rather unlikely in this area (Hinz and Schlüter, 1979 and H. C. Larsen, unpublished). A more landwards position of the OCT is therefore assumed and probably has to invoke a different break-up history. Simply to conform with the general model for the evolution of the Norwegian-Greenland Sea (fig. 12 and Talwani \& Eldholm, 1977), the excessive oceanic crust within segment 3 is assumed to have formed along a northward extension of the Reykjanes Ridge active between anomaly 20 and 7 .

A transform landwards displacement of the OCT is suggested at the northern side of the DSR, mainly to conform with the hypothesis of continental crust beneath the Faeroes (Voppel et al. 1979). Accordingly, within segment 4, the OCT is drawn slightly seawards of the mapped and/or synthetic position of anomaly 23 as the pre-A23 spreading was mainly gained by continental crust dilation (Larsen, 1978).

The deep-water area between the shelf edge and anomaly 24 in the southernmost segment 5 has been assigned an oceanic origin by Laughton (1975), whereas Featherstone et al. (1977) found evidence for a continental origin. Tentative field interpretation of aeromagnetic data from the region (Larsen \& Thorning, 1979, in press; Larsen and Thorning, unpublished) supports the latter viewpoint and the OCT is drawn at a pronounced magnetic low, slightly landwards of anomaly 24 (fig. 7).

The OCT proposed here for the East Greenland margin is tentative and can certainly be re-

Fig. 7. Part of aeromagnetic profiels recently collected offshore South East Greenland (Larsen and Thorning 1979, in press). The profiles shown are the outer parts of the southernmost extended lines shown in fig. 3. The anomaly pattern shows a double topped anomaly tentatively dated as anomaly 24 and a well developed single anomaly dated as 23 . A twinned appearance of 24 is alsa reported off Western Rockall Plateau (Roberts et al. 1979, Voppel et al., 1979) and off northern Norway (Hagevang et al, 1979). It may be related to the reverse event within anomaly 24 suggested by $\mathrm{La}$ Brecque et al. (1977), resulting in initial spreading rates ranging up to about $3.2 \mathrm{~cm} / y$ (half rates).

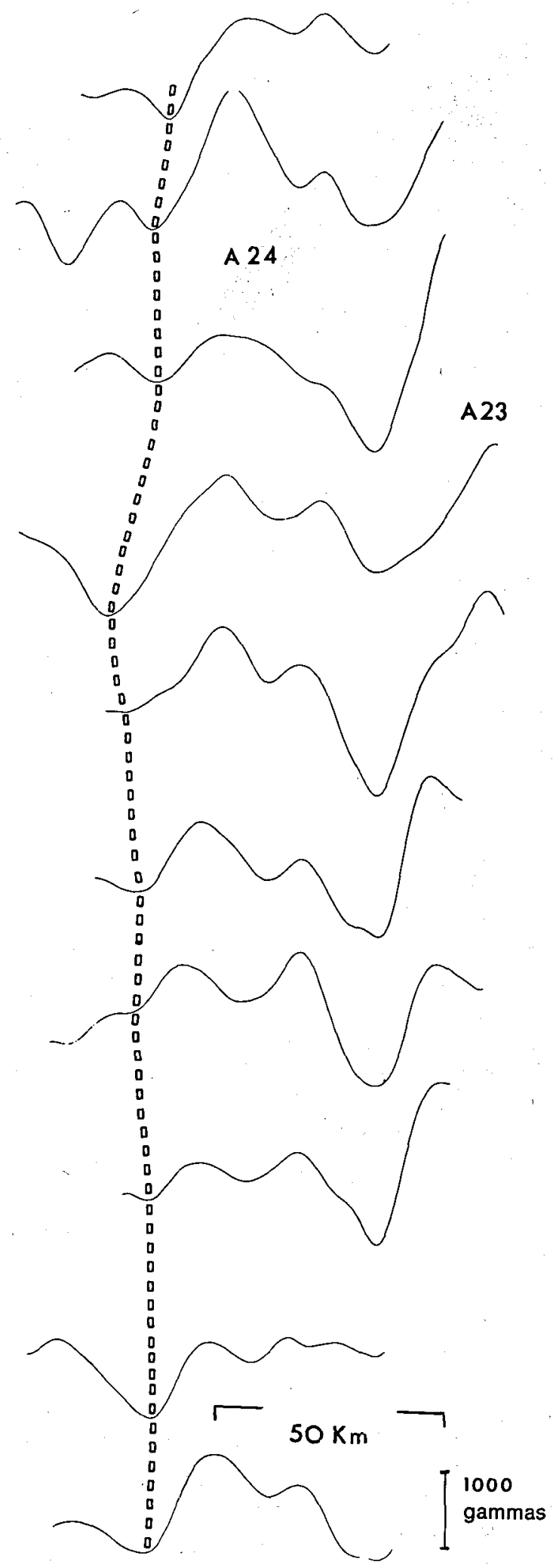




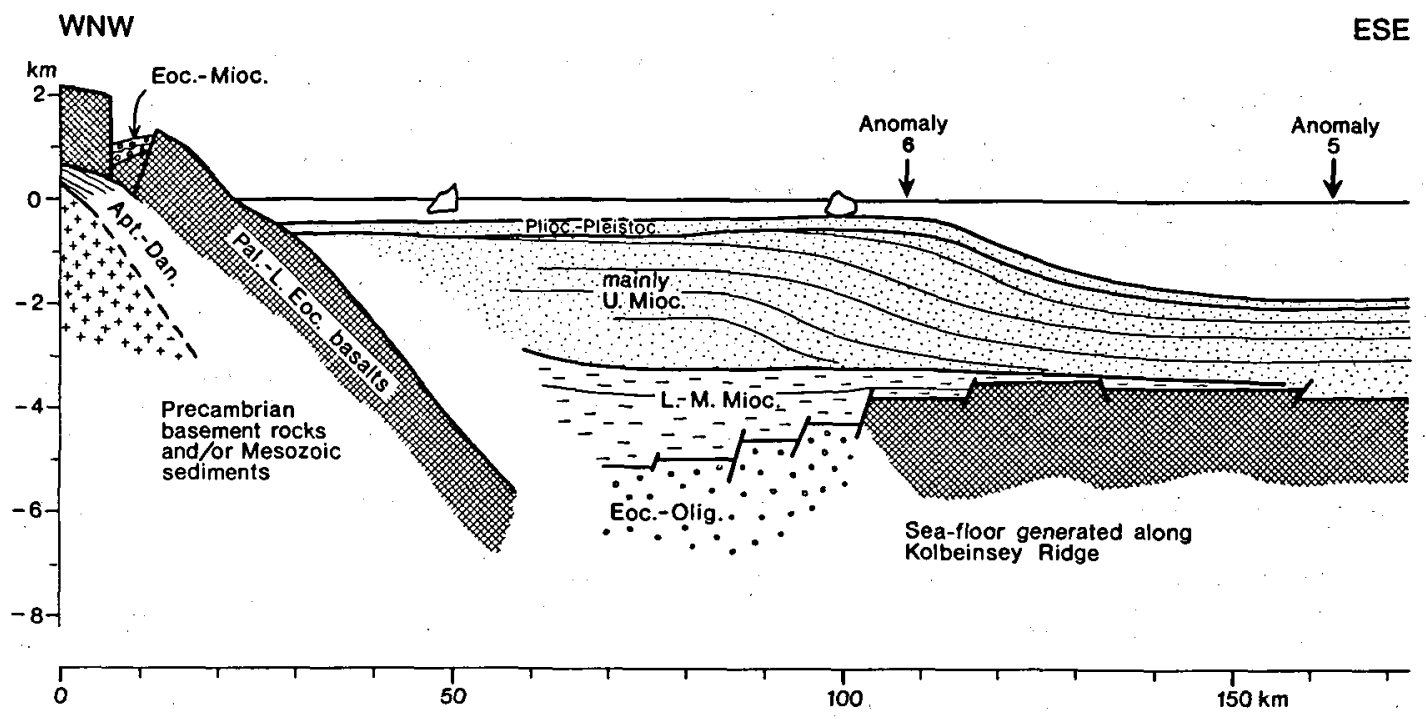

Fig. 8. Schematic cross-section of the shelf between $68^{\circ}$ and $70^{\circ} \mathrm{N}$ (sub-area B) showing the assumed deep structure. Basal Miocene unconformity on shelf contemporaneous with unconformity in onshore Eocene - Miocene sediments. Seismic data from Hinz and Schlüter $(1978,1979)$.

fined when more data become available, especially within the central parts (segment 3 and 4).

\section{d. Deep structure of the sedimentary wedge}

The extension of the sedimentary cover on the shelf is fairly well known (fig. 1), whereas much less data are available regarding its deep structure. Johnson et al. (1975a) and Larsen (1975) proposed a thickness of the wedge in the range between 3 and $7 \mathrm{~km}$. The presence of Mesozoic and in part Palaeozoic sediments was suggested on the basis of dredge samples and seismic velocity stratigraphy by Johnson et al. (1975a). The suggestion of the existence of two basins ranging up to $10 \mathrm{~km}$ in thickness (Henderson, 1976), has not been confirmed by more recent studies.

The shelf was further investigated by seismic, in part multichannel, reflection and marine gravity profiling by Durham University, U.K., Centre National pour l'Exploitation des Oceans, France, Bundesanstalt für Geowissenschaften und Rohstoffe (BGR), Western Germany, and the Geological Survey of Greenland. Interpretations of these data are given by Featherstone et al. (1977), Hinz \& Schlüter $(1978,1979)$ and B. Larsen (in press). In addition to the published information the present account also incorporates the direct use of the CNEXO-data and the BGR-data.
A threefold division of the East Greenland shelf is convenient for a discussion of the deep structure. A regional uniformity in structural style and deep structure is assumed within the three sub-areas, but they probably each comprise several sub-basins. The sub-areas comprise from north to south: (A) the region from GFZ to JMFZ, (B) from JMFZ to DSR, and (C) from DSR to Kap Farvel.

Sub-area A. At present, no data giving direct evidence for the deep structure of this area exist. However, the seismic track made by Arlis II (Ostenso, 1968), the existing aeromagnetic data (ref., see Larsen \& Thorning, 1979) and seismic data from the outermost shelf (Grønlie \& Talwani, 1978) indicates the presence of an extensive sedimentary cover. The presence of strong $\mathrm{N}-\mathrm{S}$ striking linear magnetic anomalies (fig. 1 and 5) parallel to fault scarps of assumed Mesozoic origin (Johnson et al., 1975; H. C. Larsen, unpublished) together with the extensive Mesozoic basins situated onshore and on the formerly closely adjacent Lofoten-Vesterålen area of West Norway (Jørgensen and Navrestadt, 1979; Eldholm et al., 1979) makes the presence of Mesozoic basins on the NE Greenland shelf very likely as suggested by Johnson et al. (1975a). 


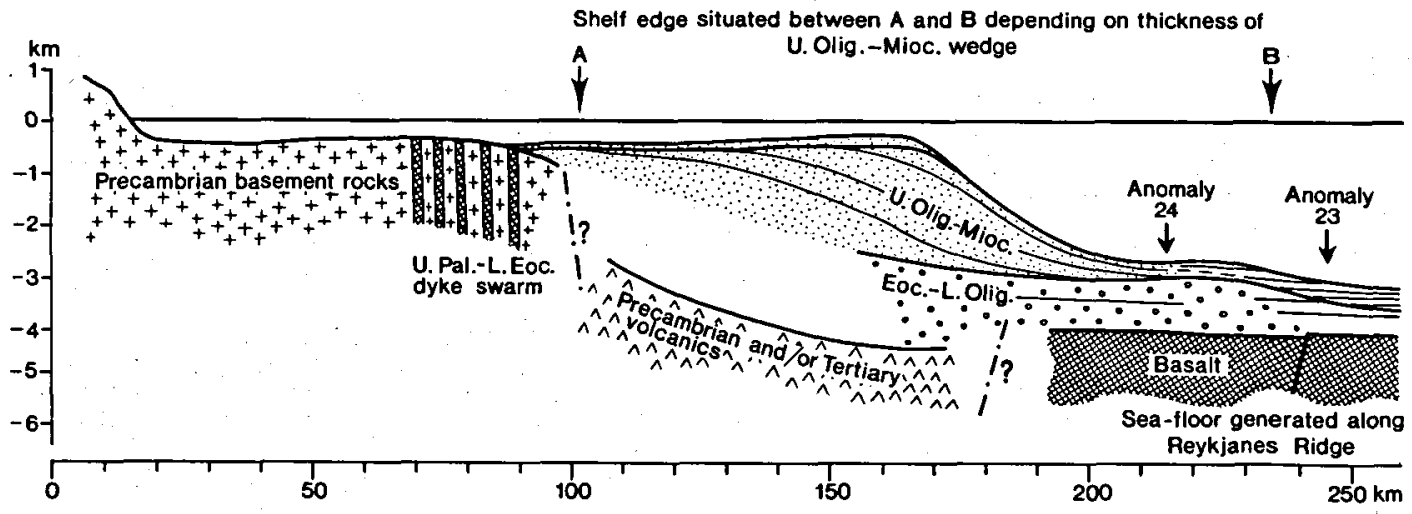

Fig. 9. Schematic cross-section of the shelf between $61^{\circ}$ and $65^{\circ} \mathrm{N}$ (sub-area C) showing the assumed deep structure. Late Cretaceous to Early Tertiary rift sediments may be present below and/or between the volcanics. Seismic data from unpublished data, Centre National pour l'Exploitation des Oceans.

Sub-area B. Depth to the acoustic and the magnetic basement in the range between 5 and 8 $\mathrm{km}$ has been reported within sub-area $B$ (Johnson et al., 1975a; Hinz \& Schlüter, 1978, 1979; H. C. Larsen, unpublished). The eastward disappearance of the Early Tertiary volcanics below the sediment points to a post-basaltic age for the whole sequence, whereas a primary absence of the volcanics due to non-deposition or erosion is considered less likely.

The existing geological and geophysical information has been compiled into a schematic crosssection (fig. 8), assuming a continuation of lavas below the offshore sediments.

The post-Oligocene sequence is dated by the seawards pinching out of assumed isochronous reflectors against sea floor of anomaly 5 to 6 ages (Hinz \& Schlüter, 1979; H. C. Larsen, unpublished).

Fig. 8 shows that about $1-2 \mathrm{~km}$ of Eocene to Oligocene sediments were deposited on top of the basalts, the latter most likely resting on Mesozoic sediments of limited thickness. The whole sequence was then faulted and subjected to erosion as spreading commenced at the nearby Kolbeinsey Ridge. A regional unconformity of Late Oligocene to Early Miocene age was formed and is followed by a well laminated sequence. It is rather poor in structures and was probably deposited in a shallow sea under stable conditions. Finally, considerable progradation of the shelf took place in the Upper Miocene when a thick sequence was deposited along the shelf margin.
Sub-area C. Between Kap Farvel and DSR a coast parallel basin cuts the shelf margin at $64^{\circ} \mathrm{N}$ (fig. 1). In this area, backwards erosion of the shelf edge and the presence of a regional unconformity, was explained as the result of strong contour current activity in the late Tertiary (Featherstone et al., 1977).

The CNEXO-data do not support the proposed cutting back of the shelf edge by erosion or the deep water origin of the prominent unconformity. The revised stratigraphy based on CNEXO-data is shown in fig. 9. According to this figure, the northward widening of the shelf is caused by strong progradation of the upper post-Oligocene unit. The same amount of progradation was not possible in the southern area due to less influx of terrigenous material and possibly also the presence of strong contour currents. Further, the regional upper unconformity is assumed to have formed at shallow depth in response to regression and subsequent transgression. It is tentatively related to the global Oligocene regression (Vail et al., 1977). In accordance with this age, the underlying transparent unit can be seen to pinch out against sea floor of approximately anomaly 13 age in the most seawards extended seismic profile (fig. 2).

The basin within sub-area $C$ is assumed to have formed during the following stages: (1) Deposition of Late Cretaceous to Early Tertiary predrift sediments. (2) Extrusion of Paleocene lavas within the rift, which form the present day acoustic and magnetic basement. (3) Collapse of the 
TABLE I

Rotation of the Greenland OCT through the pole of total opening

\begin{tabular}{|c|c|c|c|c|c|}
\hline \multicolumn{2}{|c|}{$\begin{array}{l}\text { Selected points from } \\
\text { the Greenland OCT }\end{array}$} & \multicolumn{2}{|c|}{$\begin{array}{l}\text { Rotated through modified } \\
\text { Talwani-Eldholm pole }\end{array}$} & \multicolumn{2}{|c|}{$\begin{array}{l}\text { Rotated through } \\
\text { LePichon (1977) pole }\end{array}$} \\
\hline Latitude & Longitude & Latitude & Longitude & Latitude & Longitude \\
\hline $60^{\circ} 10^{\prime} \mathrm{N}$ & $41^{\circ} 07^{\prime} W$ & $57^{\circ} 11^{\prime} \mathrm{N}$ & $23^{\circ} 05^{\prime} W$ & $55^{\circ} 11^{\prime} \mathrm{N}$ & $21^{\circ} 37^{\prime} \mathrm{W}$ \\
\hline $61^{\circ} 09 \cdot \mathrm{N}$ & $40^{\circ} 25^{\prime} \mathrm{W}$ & $58^{\circ} 03^{\prime} N$ & $22^{\circ} 02^{\prime} W$ & $56^{\circ} 04^{\prime} \mathrm{N}$ & $20^{\circ} 40^{\prime} w$ \\
\hline $62^{\circ} 37^{\prime} \mathrm{N}$ & $38^{\circ} 31^{\prime} \mathrm{W}$ & $59^{\circ} 16^{\prime} \mathrm{N}$ & $19^{\circ} 42^{\prime} \mathrm{W}$ & $57^{\circ} 20^{\prime} \mathrm{N}$ & $18^{\circ} 31^{\prime} \mathrm{W}$ \\
\hline $63^{\circ} 46^{\prime} \mathrm{N}$ & $36^{\circ} 22^{\prime} W$ & $60^{\circ} 09^{\prime} \mathrm{N}$ & $17^{\circ} 17^{\prime} \mathrm{W}$ & $58^{\circ} 15^{\prime} \mathrm{N}$ & $16^{\circ} 18^{\prime} W$ \\
\hline $64^{\circ} 09^{\prime} N$ & $35^{\circ} 01^{\prime} W$ & $60^{\circ} 23^{\prime} \mathrm{N}$ & $15^{\circ} 56^{\prime} W$ & $58^{\circ} 30^{\prime} \mathrm{N}$ & $15^{\circ} 03^{\prime} W$ \\
\hline $65^{\circ} 14^{\prime} \mathrm{N}$ & $32^{\circ} 40^{\prime} \mathrm{W}$ & $61^{\circ} 12^{\prime} \mathrm{N}$ & $13^{\circ} 24^{\prime} W$ & $59^{\circ} 22^{\prime} \mathrm{N}$ & $12^{\circ} 43^{\prime} W$ \\
\hline $67^{\circ} 30^{\prime} \mathrm{N}$ & $27^{\circ} 30^{\prime} \mathrm{W}$ & $62^{\circ} 53^{\prime} \mathrm{N}$ & $7^{\circ} 57^{\prime} \mathrm{W}$ & $61^{\circ} 10^{\prime} \mathrm{N}$ & $7^{\circ} 43^{\prime} W$ \\
\hline $67^{\circ} 13^{\prime} \mathrm{N}$ & $24^{\circ} 42^{\prime} W$ & $62^{\circ} 21^{\prime} \mathrm{N}$ & $5^{\circ} 49^{\prime} \mathrm{W}$ & $60^{\circ} 42^{\prime} \mathrm{N}$ & $5^{\circ} 39^{\prime} \mathrm{W}$ \\
\hline $68^{\circ} 47^{\prime} \mathrm{N}$ & $23^{\circ} 18^{\prime} \mathrm{W}$ & $63^{\circ} 45^{\prime} \mathrm{N}$ & $3^{\circ} 531 \mathrm{~W}$ & $62^{\circ} 08^{\prime} \mathrm{N}$ & $3^{\circ} 58^{\prime} W$ \\
\hline $70^{\circ} 24^{\prime} \mathrm{N}$ & $20^{\circ} 49^{\prime} W$ & $65^{\circ} 07^{\prime} \mathrm{N}$ & $1^{\circ} 02^{\prime} w$ & $63^{\circ} 34^{\prime} \mathrm{N}$ & $1^{\circ} 27^{\prime} W$ \\
\hline $71^{\circ} 31^{\prime} \mathrm{N}$ & $19^{\circ} 00^{\prime} \mathrm{W}$ & $66^{\circ} 03^{\prime} \mathrm{N}$ & $1^{\circ} 01^{\prime} \mathrm{E}$ & $64^{\circ} 34^{\prime} \mathrm{N}$ & $0^{\circ} 20^{\prime} E$ \\
\hline $72^{\circ} 19^{\prime} \mathrm{N}$ & $17^{\circ} 30^{\prime} \mathrm{W}$ & $66^{\circ} 43^{\prime} \mathrm{N}$ & $2^{\circ} 38^{\prime} E$ & $65^{\circ} 16^{\prime} \mathrm{N}$ & $1^{\circ} 45^{\prime} \mathrm{E}$ \\
\hline $72^{\circ} 48^{\prime} \mathrm{N}$ & $16^{\circ} 07^{\prime} W$ & $67^{\circ} 05^{\prime} \mathrm{N}$ & $3^{\circ} 58^{\prime} \mathrm{E}$ & $65^{\circ} 40^{\prime} \mathrm{N}$ & $2^{\circ} 56^{\prime} E$ \\
\hline $73^{\circ} 00^{\prime} \mathrm{N}$ & $16^{\circ} 30^{\prime} \mathrm{W}$ & $67^{\circ} 18^{\prime} \mathrm{N}$ & $3^{\circ} 48^{\prime} E$ & $65^{\circ} 53^{\prime} \mathrm{N}$ & $2^{\circ} 45^{\prime} E$ \\
\hline $73^{\circ} 20^{\prime N}$ & $15^{\circ} 10^{\prime} w$ & $67^{\circ} 32^{\prime} \mathrm{N}$ & $5^{\circ} 00^{\prime} \mathrm{E}$ & $66^{\circ} 09^{\prime} \mathrm{N}$ & $3^{\circ} 50^{\prime} \mathrm{E}$ \\
\hline $73^{\circ} 32^{\prime} \mathrm{N}$ & $15^{\circ} 33^{\prime} \mathrm{W}$ & $67^{\circ} 45^{\prime} \mathrm{N}$ & $4^{\circ} 51^{\prime} E$ & $66^{\circ} 22^{\prime} N$ & $3^{\circ} 39^{\prime} E$ \\
\hline $74^{\circ} 38^{\prime} \mathrm{N}$ & $10^{\circ} 59^{\prime} W$ & $68^{\circ} 31^{\prime} \mathrm{N}$ & $8^{\circ} 50^{\prime} \mathrm{E}$ & $67^{\circ} 14^{\prime} \mathrm{N}$ & $7^{\circ} 15^{\prime} \mathrm{E}$ \\
\hline $74^{\circ} 48^{\prime} N$ & $11^{\circ} 03^{\prime} \mathrm{W}$ & $68^{\circ} 41^{\prime} \mathrm{N}$ & $8^{\circ} 53^{\prime} E$ & $67^{\circ} 24^{\prime} \mathrm{N}$ & $7^{\circ} 17^{\prime} \mathrm{E}$ \\
\hline $75^{\circ} 33^{\prime} \mathrm{N}$ & $8^{\circ} 12^{\prime} W$ & $69^{\circ} 14 ! N$ & $11^{\circ} 21^{\prime} \mathrm{E}$ & $68^{\circ} 02^{\prime} N$ & $9^{\circ} 29^{\prime} \mathrm{E}$ \\
\hline $76^{\circ} 27^{\prime} \mathrm{N}$ & $1^{\circ} 56^{\prime} W$ & $69^{\circ} 47^{\prime} \mathrm{N}$ & $16^{\circ} 09^{\prime} \mathrm{E}$ & $68^{\circ} 44^{\prime} \mathrm{N}$ & $13^{\circ} 52^{\prime} E$ \\
\hline
\end{tabular}

Pole

Opening

Talwani-Eldholm pole (1977):

$41^{\circ} 40^{\prime} \mathrm{N}, 124^{\circ} 30^{\prime} \mathrm{E} ; 10^{\circ} 15^{\prime}$ Modified Talwani-Eldholm pole (this paper): $42^{\circ} \mathrm{N}, 124^{\circ} 30^{\prime} \mathrm{E} ; 10^{\circ} \mathrm{O} 3^{\prime}$ LePichon et al. (1977) pole: $50^{\circ} 30^{\prime} \mathrm{N}, 110^{\circ} \mathrm{E} ; \quad 12^{\circ} 30^{\prime}$ Numbering refers to fig. 8 . 


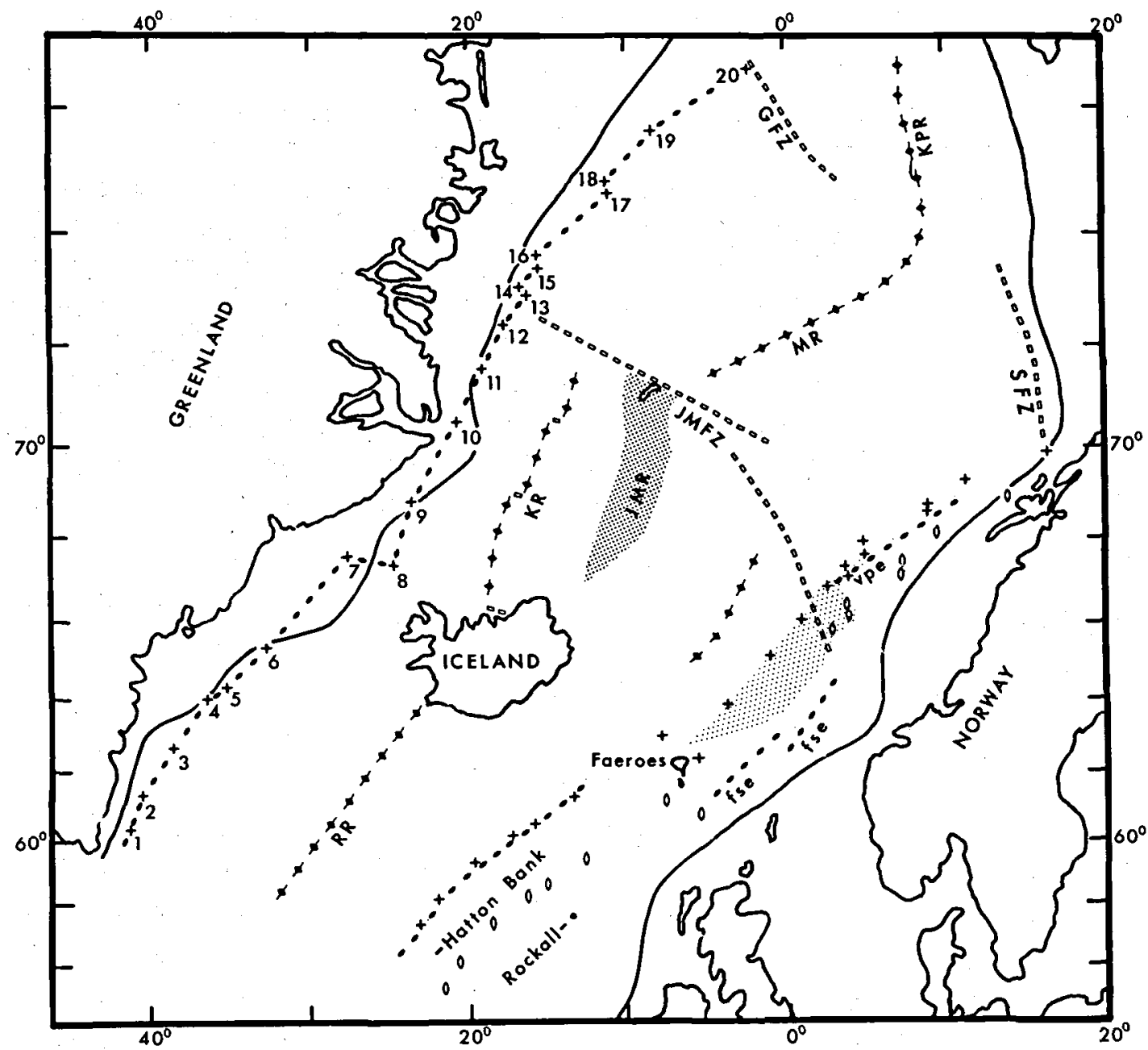

Fig. 10. Major tectonic festures of the North East Atlantic (partly from Talwani and Eldholm 1977). The East Greenland OCT is shown in its present position (numbering referring to table I) and rotated through the total pole of opening (unlabeled crosses, modified Talwani Eldholm pole, see table I). Also shown are the position of the Greenland OCT (open dots) rotated through the Le Pichon et al. pole (1977), which provide a too tight closure. Proposed OCT off NW Europe (shown by heavy dots) from Roberts et al. (1979) and Voppel et al. (1979) to the south of the Faeroes, to the north of the Faeroes from Talwani and Eldholm (1977). Note the very good pre-drift fit off Rockall - Hatton Bank and off northern Norway. The data indicates that initial rifting took place slightly seawards of the Vøring Plateau Escarpment (VPE). The fit between the Faeroes and Jan Mayen Fracture Zone (JMFZ) is uncertain, due to the rather poor knowledge of the deep structure of the Jan Mayen Ridge (JMR), but indicates an OCT slightly seawards of the Faeroe - Shetland Escarpment (fse). Note the overlap between the JMR and the continental crust south of the vpe (see text for discussion). KR: Kolbeinsey Ridge. MR: Mohns Ridge. KPR: Knipovitch Ridge. GFZ: Greenland Fracture Zone. SFZ: Senja Fracture Zone.

former rift and deposition of the transparent sequences of inferred Eocene to Oligocene age. (4) Regional Oligocene regression and formation of the upper conformity followed by subsidence and strong progradation of the northern part of the shelf.

Formation of marginal sea-floor ridges related to the major fjord-channel systems was initiated prior to the formation of the Oligocene uncon- formity (fig. 9) and thus points to a much older origin of these than previously proposed (Sommerhoff, 1973; Johnson et al., 1975b).

The proposed structure within area $\mathrm{C}$ is in good agreement with the general evolution of the formerly closely attached western Rockall Plateau (Roberts et al. 1979), and the assumed stratigraphy is confirmed by the dredge samples yielding Tertiary ages (Johnson et al., 1975a). 


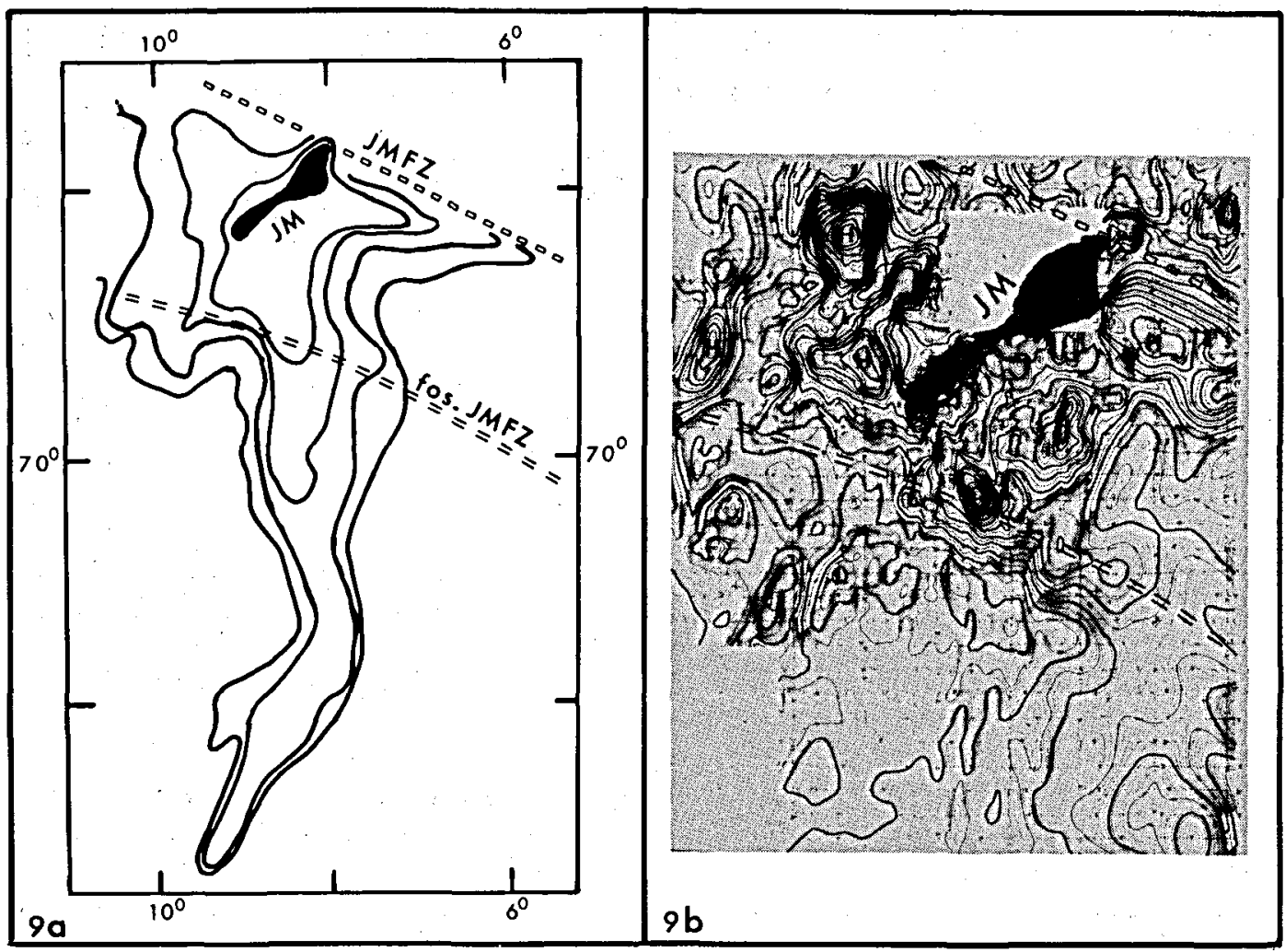

Fig. 11. Bathymetry (9a) and aeromagnetics (9b) from the northern part of the Jan Mayen Ridge. The suggested change in crustal nature (see text for discussion) is assumed to correlate with the postulated fossil part of Jan Mayen Fracture Zone(JMFZ). Note the associated offset in bathymetry and the change from a magnetic smooth zone in the south (assumed continental crust) to a magnetic high frequency area in the north (assumed oceanic crust). JM: Jan Mayen. From Navrestad and Jørgensen (1979).

\section{Plate tectonic implications}

\section{a. Rotation through the pole of opening}

The definition of an ocean-to-continent transition for the East Greenland margin provides a possibility to test poles of total opening proposed by various authors. The results of a backwards rotation using the Le Pichon pole and a modified Talwani-Eldholm pole (Le Pichon et al., 1977, Talwani and Eldholm, 1977 and this paper) is shown in figure 10 and table I. Correcting for the Jan Mayen micro continent, a very good closure is obtained by the Talwani-Eldholm pole and is only slightly improved by modifications of the pole. The Le Pichon pole seems definitely to imply a too tight closure - quite surprisingly, as it was based on the $2000 \mathrm{~m}$ isobath, which in most cases lies seawards of the OCT presented here.

Crossings of the OCT with major fracture zones provide a tool for the test of the latitudinal correctness of a fit. Unfortunately, only one such crossing is safely identified on both margins of the NE-Atlantic, namely the crossings of the OCT with the Greenland Fracture Zone and the OCT with the Senja Fracture Zone (fig. 8).

Prominent offsets or flexuring in the earliest sea floor spreading anomalies provide another testing of the latitudinal fit, but requires detailed magnetic coverage of both margins. Comparisons of the Greenland magnetic data (fig. 3, Larsen and Thorning, 1979 and in press) with data off the Western Rockall Bank (Vogt and Avery, 1974) testifies the general correctness of the Talwani-Eldholm pole and points to a position of the Le Pichon pole (Le Pichon et al., 1977) about 14 degrees too much to the west. It is felt that the application of the slightly modified Talwani-Eldholm pole (table I) places NW-Europe and Greenland in their relative pre-Tertiary positions with an accuracy of about $25 \mathrm{~km}$. 
The pre-anomaly 13 part of the JMFZ is not known from the Greenland Margin although suggestions for its prolongation into the fiord zone have been published (Johnson et al., 1975a, Surlyk, 1978b). Backwards rotation of the intersection of the Greenland OCT with the extrapolated trend of the post anomaly-13 JMFZ plots considerably inside the Inner Vøring Plateau (fig. 8), except the Le Pichon pole is used, and therefore points to a pre-anomaly 13 position of the JMFZ against the Greenland Margin to the south of its present position.

Moving the Jan Mayen Ridge eastwards along the calculated flowlines (Talwani and Eldholm, 1977), a good longitudinal fit has been obtained (fig. 10). One exception is a considerable overlap between the northern part of the Jan Mayen Ridge and the southern Inner Vøring Plateau, both believed to be of continental origin (Talwani and Udintsev, 1976, Talwani and Eldholm, 1977). A possible oceanic origin for the northernmost part of the Jan Mayen Ridge correlates well with a first order boundary within the aeromagnetic map and a prominent offset in morphology (fig. 11 and Navrestad and Jørgensen, 1979).

\section{b. Rifting}

Direct information on possible late Cretaceous to earliest Tertiary rifting genetically related to the subsequent continental separation within the NE-Atlantic are almost absent. Even incorporating the material provided through the DSDP - drilling, exposures of possible rift sediments are restricted to the scattered occurrence in East Greenland. In contrast, Tertiary sediments of post-drift age are widespread. Especially huge accumulations occur on the Middle and South East Greenland shelf, being bounded landwards by a major monoclinal flexure (fig. 1, $8,9)$. If by any means in isostatic balance, the post-Palaeocene subsidence and basin formation offshore East Greenland must imply considerable crustal attenuation. I therefore suggest these areas also to have been the site of late Cretaceous/early Tertiary rifting (and crustal attenuation), and the East Greenland flexure as its approximate western boundary (fig. 1 and 12). The Inner Vøring Plateau and associated Vøring Plateau Escarpment is interpreted as the north- ern continuation of the late Cretaceous to early Tertiary rift and its western boundary (fig. 12).

The latter suggestion requires a reinterpretation of this debated feature (Talwani and Eldholm, 1972, 1977, Hinz, 1972, Rønnevik et al., 1979). The present interpretation assigns a continental origin for the inner part of the Outer Vøring Plateau - which could explain its abnormal elevation - and points towards a more extensive occurrence of late Cretaceous and Tertiary sediments (and volcanics?) on the Inner Vøring Plateau than hitherto accepted.

According to fig. 12 , the proto rift mainly remained fixed to the NW-European margin to the north of JMFZ, and consequently, the post drift subsidence played a much less important role on this part of the Greenland margin - a feature this area may have in common with the Barents Sea area (Rønnevik and Motland, 1979).

\section{c. Spreading history}

Minor revisions of the Tertiary spreading history (fig. 12) has been invoked into the general model proposed by Talwani and Eldholm (1977).

As evidenced by the Greenland magnetic data (fig. 3 and 5), minor transforms and jumps of spreading axis occurred on the southern part of Mohns Ridge within the early stage of spreading.

Within the same area, a slightly northward migrating (about $1 \mathrm{~cm} / \mathrm{y}$ ) central volcanic activity produced a prominent basement ridge between anomaly 20 and 13 (fig. 1, 12 and paragraph on morphology).

A new, more northern position of the JMFZ was established around anomaly 7 to 6 time when spreading ceased around Aegir Ridge and commenced around the present day active Kolbeinsey Ridge (this paper and Vogt et al., 1980) without the intermediate position on the Icelandic Plateau suggested by various authors and adapted by Talwani and Eldholm (1977). By this combined jump of spreading axis and the JMFZ, the southern tip of Mohns Ridge between the old and new position of JMFZ became an extinct axis (fig. 13), and a fragment of the Greenland margin became part of the Eurasic plate. This micro-continent, together with the volcanic active Jan Mayen, now forms the morphological unit referred to as the Jan Mayen Ridge, but in contrast to Talwani and Udintsev (1976) and Talwani and Eldholm (1977), oceanic crust (late Oligocene to 

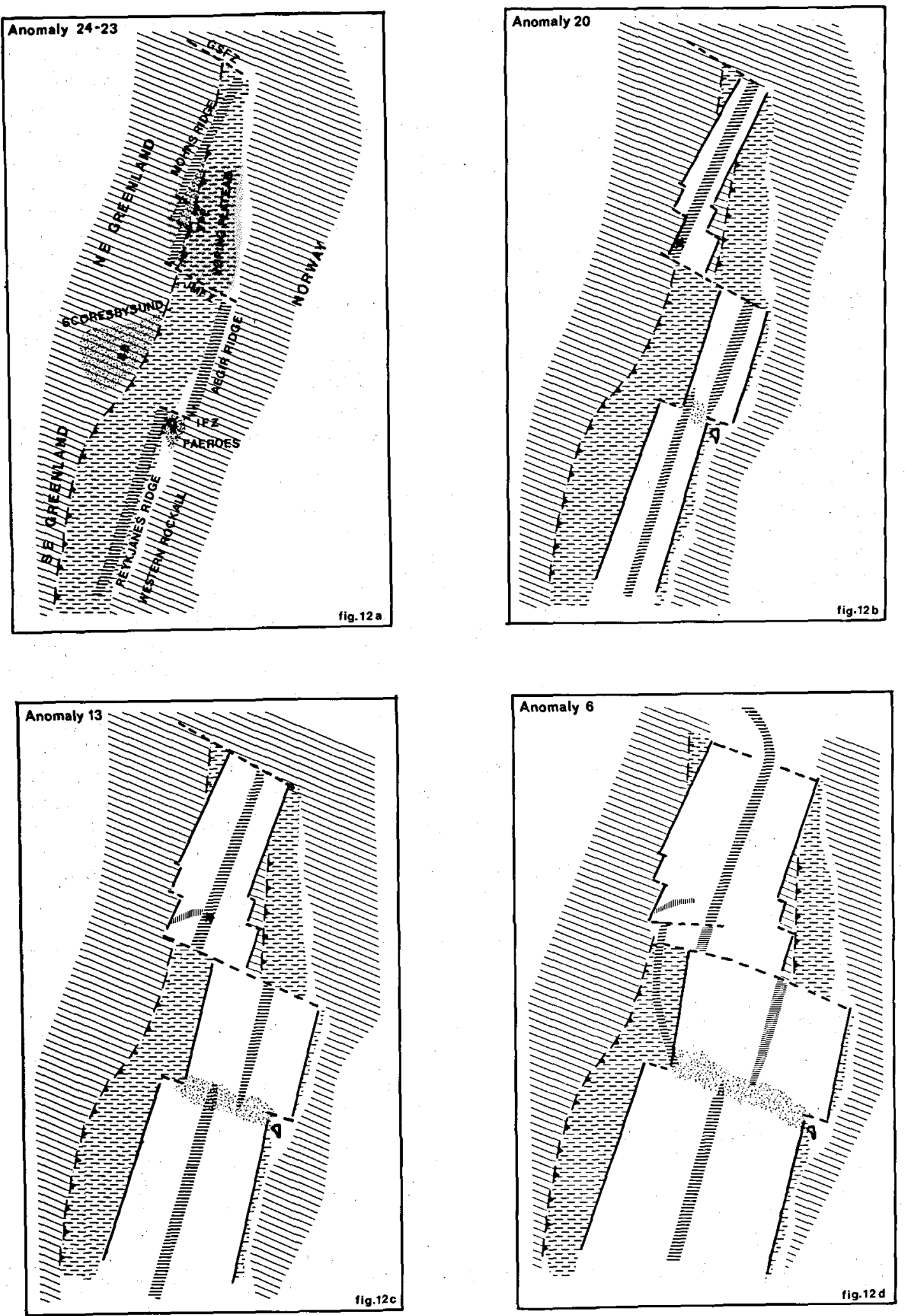


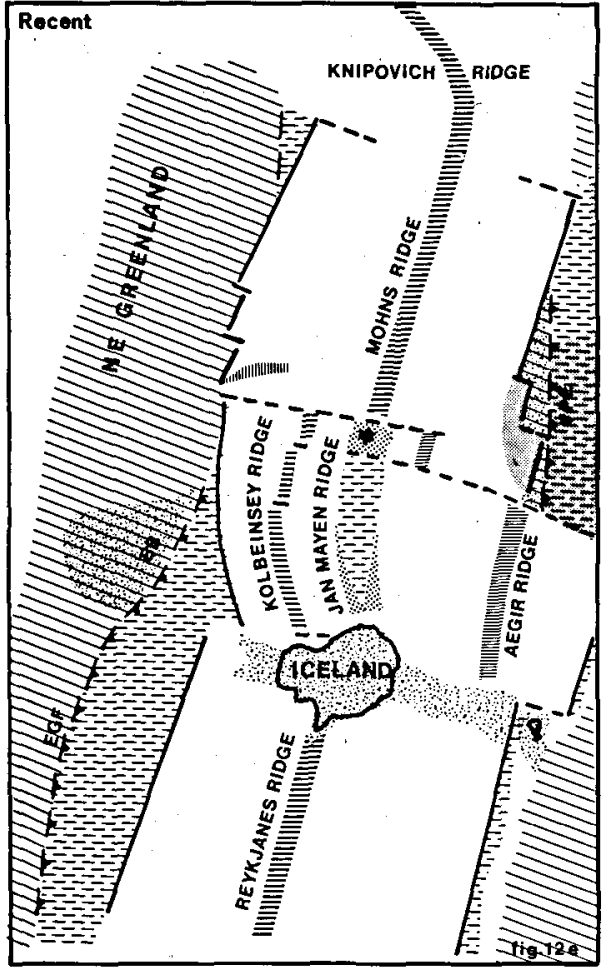

early Miocene in age) is suggested to underly the northernmost part of the ridge (fig. 12).

\section{Petroleum geological aspects}

The account presented here is tentative, based on rather few data and fundamental questions such as crustal nature below part of the shelf and the offshore extension of pre-Tertiary sediments below the Early Tertiary lavas cannot be answered at the present stage. The exploration technique to be applied in this harsh environment partly belongs to the future. For this reason, a proper petroleum geological assessment must await future work and only a few comments will be given here.

Sub-area $\mathrm{A}$ is an obvious target for petroleum exploration. Mature source rocks and good reservoirs are reported onshore and a proper burial and capping of the equivalent Mesozoic sediments is expected offshore (Henderson, 1976; Unpublished reports on open file in Geol. Surv. Greenland).

Sub-area B has sufficient thickness of sediments (fig. 1) to make it petroleum geological attractive, although the area has the serious disadvantage of the very recent (Miocene) subsidence of the basin. The potential for oil and gas should be best within the Eocene to Oligocene sequence (fig. 8) where good structures occur seawards and porosity and permeability could be reasonable as the sequence is assumed to comprise coarse clastics. The unconformably overlying, well laminated Lower Miocene sequence may constitute a proper cover. At greater depth, gas shows may be present below the basalt if a sufficient Mesozoic sequence is preserved. The rather high methane content of some warm springs at the coast has been assigned to the presence of bituminous sediments below the lavas (W. S. Watt, personal communication, 1979).

Fig. 12. Cartoons showing the previous established evolution of the NE-Atlantic (Talwani and eldholm, 1977) and the modifications proposed in this paper. The assumed late Cretaceous to early Tertiary rift off SE Greenland (horizontal hatching) is assumed to continue northward into the Vøring Plateau, and the associated East Greenland Flexure (EGF in 12e) into the Vøring Plateau Escarpment (VPE). Volcanism within the rift led to the formation of extensive plateau basalts just prior to spreading [Blosseville basalts (BB), The Faeroes and Outer Voring Plateau].

Minor transform faults and jump of axis occurred on the southern Mohns Ridge prior to anomaly 20.

Between anomaly 20 and 13, central type volcanism on the southern Mohns Ridge led to the formation of a prominent high (see also fig. 1 and paragraph on morphology). At the same time, twin axial apreading in the area of the former Iceland Fracture Zone (IFZ) led to the fan shaped anomaly pattern in the Norwegian Sea (Talwani and Eldholm, 1977), and possibly also the incipient formation of the Faeroe - Iceland - Greenland Ridge. At anomaly 6-time, the combined jump of the spreading axis from the Norwegian Sea onto the Greenland Margin, and the northward displacement of the Jan mayen Fracture Zone (JMFZ), led to the formation of the Jan Mayen Ridge micro-continent and the extinction of the southernmost part of the Mohns Ridge (see also fig. 13).

The commencement of spreading, in part outside and slightly oblique to the former rift is responsible for the present day configuration, with most of the late Cretaceous/early Tertiary rift attached on the Greenland margin to the south and to the north on the NW-European margin.

The even more ablique strike of the spreading centers in relation to the Mesozoic rift-systems (Viking Graben, Central East Greenland rift, not shown in fig.) had a similar effect, preserving the rifts on the $N W$ European margin in the south and mainly on the Greenland margin to the north.

GSFZ: Greenland - Senja Fracture Zane. 


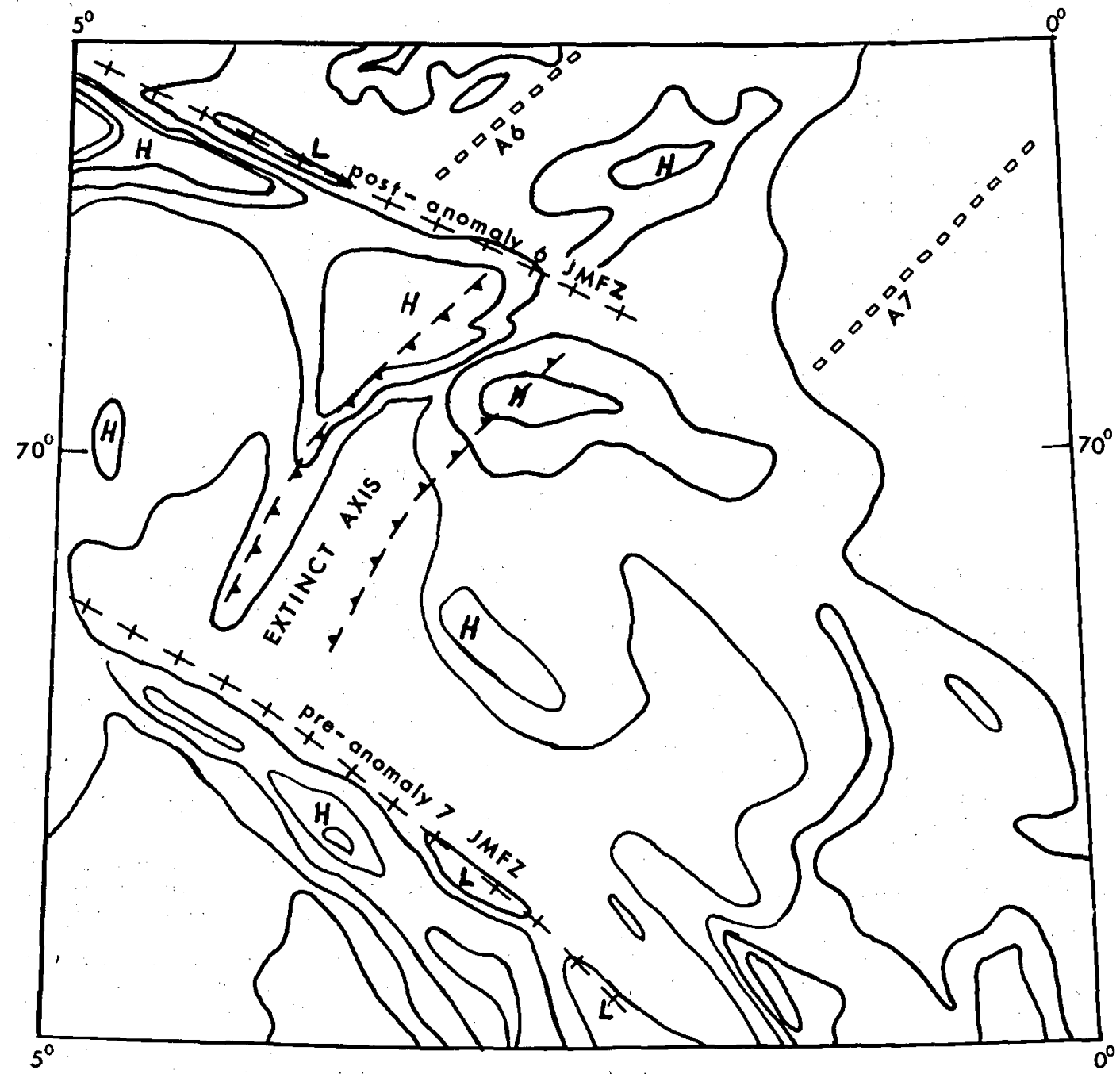

Fig. 13. Bathymetric map ( $400 \mathrm{~m}$ equidistance) showing the existence of a submarine rift-valley morphology between the two different parts of the Jan Mayen Fracture Zone (JMFZ). This feature is interpreted as an extinct fragment of the Mohns Ridge where spreading ceased between anomaly 6 and 7 (see fig. 12 and in the text). This interpretation is strongly supported by the configuration of anomaly 6 and 7 to the north of the present active JMFZ (position of anomalies from Gronlie and Talwani, 1978). Bathymetry from Perry et al. (1977).

Sub-area $\mathrm{C}$ only shows moderate thickness of sediments, at least above the magnetic basement interpreted as Early Tertiary lavas (fig. 9). Maximum thickness seems to occur (fig. 1) between $64^{\circ}$ and $65^{\circ} \mathrm{N}$ and here some potential for oil and gas may be present within the post drift sediments. As in sub-area B, gas, and maybe also oil, could be present below lavas depending on the pre-drift geological record. Sub-area $C$ is the only area offshore East Greenland where present day exploration techniques seem applicable on a wider basis.
Acknowledgements. Thanks are due to K. Hinz, Hannover, $L$. Montadert, Paris, A. Marty, Paris, and L. Thorning, Copenhagen, for their kind permission to make use of unpublished data and to F. Surlyk, L. Clemmensen and C. K. Brooks for reviewing the manuscript. W.S. Watt and F. Rolle corrected the text. Nils Jacobsen assisted throughout the compilation of the data and made the programme for rotation of coordinates through the pole of opening. The paper was written while holding a grant from the Danish Energy Agency and is published with the permission of the Director of the Geological Survey of Greenland. 


\section{Dansk sammendrag}

Den nordlige del af den østgrønlandske kontinentale margin viser spor af pladeseparationer- og kollisioner af aldre fra tidlig Prakambrium til nedre Palæozoikum (Kaledonisk) efterfulgt af postkaledonisk molasse sedimentation og Mesozoisk riftdannelse. Den sydlige del udgjorde tilsyneladende en stabil kraton blok fra midt Prækambrium til sen Mesozoikum. Den østgrønlandske margin blev adskilt fra den NV-Europæiske margin i $\varnothing v$ re Paleocæn til Nedre Eocen, da havbundsspredning startede i NØ-Atlanten og udgør i dag en passiv rifted margin. De Tertiære aflejringer omfatter bl.a. mindre forekomster af præ-drift sedimenter overlejret af 1-7 km tykke $\emptyset \mathrm{vre}$ Paleocæne basaltiske lavaer ekstruderet umiddelbart inden start af havbundsspredningen. En efterfølgende kraftig indsynkning af shelfområderne medforte aflejring af 2-8 $\mathrm{km}$ tykke lag af post-basaltiske sedimenter på shelfen, hvorimod landområderne hævedes 1-2 km. Havbundsspredning omkring Kolbeinsey Ryggen startede i $\emptyset_{\mathrm{vre}}$ Oligocæn og blev ledsaget af fornyet forkastnings aktivitet $i$ den midterste del af marginen. En betydelig progradering af shelfranden fandt sted i Miocan tid. Rotation gennem den totale åbningspol af en foreslået ocean-kontinent grænse viser, at anvendelsen af en modificeret TalwaniEldholm pol tilvejebringer en præ-drift position uden væsentlige overlap eller gab mellem de to marginer i området mellem den sydligste spids af Grønland og Grønland - Senja transform forkastningen i nord. En sammenligning af den grønlandske margin med Vøring Plateauet medfører en dannelseshistorie af sidstnævnte forskellig fra den af Talwani og Eldholm foreslåede. Der præsenteres nogle mindre andringer af spredningshistorien, bl.a. gentagen vestlig forskydning af Mohns Ryggen mellem anomali 24 og 21, start af spredning omkring Kolbeinsey Ryggen senest ved anomali 6 tid og $\mathrm{i}$ forbindelse hermed, aktivering af den recente aktive del af Jan Mayen transform forkastningen nord for dens tidligere position.

Området mellem den fossile del af Jan Mayen transform forkastningen og dens recent aktive del omfatter den nordligste del af Jan Mayen Ryggen og foreslås at være dannet omkring en sydlig forlængelse af Mohns Ryggen, som var aktiv til omkring anomali 6 tid og den beregnede position af dette fossile spredningsakse-fragment stemmer overens med de bathymetriske forhold.

\section{References}

Anwar, Y. M. 1955: Geological investigations in East Greenland. V. Petrography of Wales Bjerge lavas. Meddr Gronland $135,1,31 \mathrm{pp}$.

Birkelund, T. \& Perch-Nielsen, K. 1976: Late Palaeozoic-Mesozoic evolution of central East Greenland. In Escher, A. \& Watt, W. S. (edit.) Geology of Greenland, 304-339. Copenhagen: Geol. Surv. Greenland.

Birkenmajer, K. 1972: Report on investigations of Tertiary sediments at Kap Brewster, Scoresby Sund, East Greenland. Rapp. Grenlands geol. Unders. 48, 85-91.

Bott, M. H. P. \& Watts, A. B. 1971: Deep structure of the continental margin adjacent to the British Isles. In The Geology of the East Atlantic Continental Margin. Inst. Geol. Sci., Rept. 70/14, 89-109.

Bridgwater, D., Davies, B., Gill, R. C. O., Gorman, B. E., Myers, J. S., Pedersen, S. \& Taylor, P. 1978: Precambrian and Tertiary geology between Kangerdlugssuaq and Angmagssalik, East Greenland. Rapp. Grønlands geol. Unders. 83, 17 pp.
Brooks, C. K. 1973: Tertiary of Greenland - A volcanic and plutonic record of continental break-up. Arctic Geology. Amer. Ass. Petrol. Geol., Memoir 19, 150-160.

Brooks, C. K. 1979: Geomorphological observations at Kangerdlugssuaq, East Greenland. Greenland Geosci. 1, 21 pp.

Brooks, C. K. \& Gleadow, A. J. W. 1977: A fission-track age for the Skaergaard intrusion and the age of the East Greenland basalt. Geology 5, 539-540.

Brooks, C. K., Nielsen, T. F. D. \& Petersen, T. S. 1976: The Blosseville Coast basalts of East Greenland: their occurrence, composition and temporal variations. Contr. Miner. and Petrol. 58, 279-292.

Brooks, C. K., Pedersen, A. K. \& Rex, D. C. 1979: The petrology and age of alkaline mafic lavas from the nunatak zone of central East Greenland. Bull. Gronlands geol. Unders. 133, $28 \mathrm{pp}$.

Brooks, C. K. \& Rucklidge, J. C., 1974: Strongly undersaturated lavas Tertiary volcanic rocks from the Kangerdlugssuaq area, East Greenland. Lithos 7 , 239-248.

Bullard, E., Everett, J. A. \& Smith, A. G. 1965: The fit of the continents around the Atlantic. Philosophical Transactions of the Royal Society of London, A, 258, 41-75.

Bütler, M. 1959: Das Old Red-Gebiet am Moskusoksefjord. Meddr Gronland 160, 5, 188 pp.

Bütler, M. 1961: Continental Carboniferous and Lower Permian in central East Greenland. In Raasch, G. O. (edit.) Geology of the Arctic, vol. 1, 205-213 (Toronto U. P.).

Clemmensen, L. B. 1978a: Alternating aeolian, sabkha and shallowlake deposits from the Middle Triassic Gipsdalen Formation, Scoresby Land, East Greenland. Palaeogeogr. Palaeoclimatol. Palaeoecol. 24, 111-135.

Clemmensen, L. B. 1978b: Lacustrine facies and stromatolites from the Middle Triassic of East Greenland. J. sedim. Petrol. 48, 1111-1128.

Clemmensen, L. B. 1979: Triassic lacustrine red-beds and palaeoclimate: The "Buntsandstein" of Helgoland and the Malmros Klint Member of East Greenland. Geol. Rdsch. $68,748-774$.

Clemmensen, L. B. 1980: Triassic rift sedimentation and palaeogeography. Bull. Grenlands geol. Unders. 136.

Collinson, J. D. 1972: The Røde $\emptyset$ conglomerate of inner Scoresby Sund and the Carboniferous(?) and Permian rocks west of the Schuchert Flod. Bull. Grenlands geol. Unders. $102,48 \mathrm{pp}$.

Deer, W. A. 1976: Tertiary igneous rocks between Scoresby Sund and Kap Gustav Holm, East Greenland. In Escher, A. \& Watt, W. S. (edit.) Geology of Greenland, 404-430. Copenhagen: Geol. Surv. Greenland.

Eldholm, O., Sundvor, E. \& Myhre, A. 1979: Continental margin off Lofoten-Vesterålen, Northern Norway. Mar. Geophys. Res. 4, 3-35.

Eldholm, O. \& Windisch, C. C. 1974: Sediment Distribution in the Norwegian-Greenland Sea. Bull. geol. Soc. Amer. 85, 1661-1676.

Faller, A. M. 1975: Palaeomagnetism of the oldest Tertiary basalts in the Kangerdlugssuaq area of East Greenland. Bull. geol. Soc. Denmark 24, 173-177.

Faller, A. M. \& Soper, N. J. 1979: Palaeomagnetic evidence for the origin of the coastal flexure and dyke swarm in central E Greenland. J. geol. Soc. London, vol. 136, 737-744.

Featherstone, P. S., Bott, M. H. P. \& Peacock, J. H. 1977: Structure of the Continental Margin of South-Eastern Greenland. Geophys. J. R. astron. Soc. 48, 15-77.

Grønlie, G. \& Talwani, M. 1978: Geophysical Atlas of the Norwegian Greenland Sea. VEMA Res. Ser. IV, Lamont-Doherty Geol. Observatory, Palisades, N. Y.

Hagevang, F., Eldholm, O. \& Aalstad, I. 1979: Tidlig havbunnspredning mellom Jan Mayen og Grønland - Senja 
bruddsonene. Abstract, 14. Nordiske geol. v. mote 1980, Norsk geol. Forening, Geolognytt 13, 26.

Hald, N. 1978: Field investigations of Tertiary basic igneous rocks between $72^{\circ}$ and $73^{\circ} 30^{\prime} \mathrm{N}$, northern East Greenland. Rapp. Gronlands geol. Unders. 90, 109-113.

Hald, N. 1979: Tertiary igneous activity at Giesecke Bjerge, northern East Greenland. Bull. Geol. Soc. Denmark 27, Special Issue, 109-115.

Haller, J. 1956: Geologie der Nunatakker Region von Zentral -Ostgrönland zwischen $72^{\circ} 30^{\prime}$ und $74^{\circ} 10^{\prime}$ n.Br. Meddr Grønland 154, 1, 1-172.

Haller, J. 1970: Tectonic map of East Greenland $(1: 500,000)$. An account of tectonism, plutonism, and volcanism in East Greenland. Meddr Grønland 171, 5, $286 \mathrm{pp}$.

Haller, J. 1971: Geology of the East Greenland Caledonides, 413 pp. New York: Interscience Publishers.

Hassan, M. Y. 1953: Tertiary faunas from Kap Brewster, East Greenland. Meddr Grønland 111, 5, 42 pp.

Henderson, G. 1976: Petroleum geology. In Escher, A. \& Watt, W. S. (edit.) Geology of Greenland, 488-505. Copenhagen; Geol. Surv. Greenland.

Higgins, A. K. \& Phillips, W. E. A. 1979: East Greenland Caledonides - an extension of the British Caledonides. In Holland, C, H. \& Leake, B. E. (edit.) The Caledonides of the British Isles - reviewed. Geol. Soc. London, spec. publ. 8, 19-32.

Hinz, K. 1972: Der Krustenaufbau der norwegischen Kontinentalrandes (Voring Plateau) und der norwegischen Tiefsee zwischen $66^{\circ}$ und $68^{\circ} \mathrm{N}$ nach sejsmischen Untersuchungen. Meteor Forsch-Ergebnisse, Reihe $C$ no 10 1-16.

Hinz, K. v. \& Schlüter, H.-U. 1978: The North Atlantic - results of geophysical investigations by the Federal Institute for Geosciences and Natural Resources on North Atlantic continental margins. Erdöl-Erdgas-Zietschrift 94. Jg., 271-280.

Hinz, K. \& Schlüter, H.-U. 1979: The continental margin of East Greenland. Preprint of The Tenth World Petroleum Congress, special Paper no. 7, Heyden \& Son Ltd.

Johnson, G. L., McMillan, N. J. \& Egloff, J. 1975a: East Greenland Continental Margin. In C. J. Yorath, E. R. Parker \& D. J. Glass (edit.) Canada's continental margins and offshore petroleum exploration. Mem. Can. Soc. petrol. Geol. 4, 205-224.

Johnson, G. L., Sommerhoff, G. \& Egloff, J. 1975b: Structure and morphology of the west Reykjanes basin and the southeast Greenland continental margin. Mar. Geol. 18, 175-196.

Jørgensen, F. \& Navrestadt, T. 1979: Main structural elements and sedimentary succession on the shelf outside Nordland (Norway). NSS/11, 1-20. Proceedings, Norwegian Sea Symposium, Tromsø 1979. Norwegian Petroleum Society, Oslo.

Katz, H. R. 1952: Ein Querschnitt durch die Nunatak-Zone Ostgrönlands. Meddr Grenland 144,8, 65 pp.

Kempter, E. 1961: Die Jungpaläozoischen Sedimente von Süd Scoresby Land. Meddr Gronland 164, 1, 123 pp.

LaBrecque, J. L., Kent, D. V. \& Cande, S. C. 1977: Revised magnetic polarity time scale for Late Cretaceous and Cenozoic time. Geology 5, 330-335.

Larsen, B. 1975: Marine geophysical survey of the East Greenland shelf south of Angmagssalik. Rapp. Gronlands geol. Unders. 75, 87-88.

Larsen, B. in press: A marine geophysical survey of the continental shelf of East Greenland $60^{\circ}-71^{\circ} \mathrm{N}$ - Project Dana 79. Rapp. Gronlands geol. Unders. 100, 94-98.

Larsen, H. C. 1975: Aeromagnetic investigations in East Greenland. Rapp. Gronlands geol. Unders. 75, 88-91.

Larsen, H. C. 1978: Offshore continuation of East Greenland dyke swarm and North Atlantic Ocean formation. Nature $274,220-223$.
Larsen, H. C. \& Thorning, L. 1979: Project EASTMAR: planning of an aeromagnetic survey off East Greenland. Rapp. Grønlands geol. Unders. 95, 93-96.

Larsen, H. C. 1979a: Geological perspectives of the East Greenland continental margin. Abstracts, Norwegian Sea Symposium, Tromsø 1979. Norwegian Petroleum Society, Oslo.

Larsen, H. C. 1979b: Østgrønlands ocean til kontinent grænse. Abstract, 14. Nordiske geol. v. møte 1980, Norsk geol. Forening, Geolognytt 13, 40.

Larsen, H. C. \& Thorning, L. in press: Project EASTMAR: acquisition of high sensitivity aeromagnetic data off East Greenland. Rapp. Gronlands geol. Unders. 100, 91-94.

Laughton, A. D. 1975: Tectonic evolution of the Northeast Atlantic Ocean; a review. Norges geol. Unders. 316, 169-193.

Le Pichon, X., Sibuet, J.;C. \& Francheteau, J. 1977: The fit of the continents around the North Atlantic Ocean. Tectonophysics 38, 169-209.

Maync, W. 1942: Stratigraphie und Faziesverhältniss der oberpermischen Ablagerungen Ostgrönlands (olim "Überkarbon-Unterperm") zwischen Wollaston Forland und dem Kejser Franz Josephs Fjord. Meddr Gronland $115,2,128 \mathrm{pp}$.

Maync, W. 1949: The Cretaceous Beds between Kuhn Island and Cape Franklin (Gauss Peninsula), northern East Greenland. Meddr Grenland 133, 3, 291 pp.

Myers, J. S. in press: Structure of the coastal dyke swarm and associated plutonic intrusions of East Greenland. Earth planet. Sci. Lett.

Navrestad, T. and Jørgensen, F. 1979: Aeromagnetic investigations on the Jan Mayen Ridge. NSS 19, 1-5. Proceedings, Norwegian Sea Symposium, Tromsø 1979. Norwegian Petroleum Society, Oslo.

Nielsen, T. F. D. 1975: Possible mechanism of continental break-up in the North Atlantic. Nature 253, 182-184.

Nielsen, T. F. D. 1978: The Tertiary dike swarms of the Kangerdlugssuaq area, East Greenland: Contr. Miner. Petrol. 67, 63-78.

Noe-Nygaard, A. 1976: Tertiary igneous rocks between Shannon and Scoresby Sund, East Greenland. In Escher, A. \& Watt, W. S. (edit.) Geology of Greenland, 386-404. Copenhagen: Geol. Surv. Greenland.

Noe-Nygaard, A. \& Pedersen, A. K. 1974: Progressive chemical variation in a tholeiitic lava sequence at Kap Stosch, northern East Greenland. Bull. geol. Soc. Denmark 23, $175-190$

Ostenso, N. A. 1968: Geophysical studies in the Greenland Sea. Bull. geol. Soc. Amer. 79, 107-132.

Perry, R. K., Fleming, H. S., Cherkis, N. Z., Feden, R. H. \& Massingill, J. V. 1977: Bathymetry of the NorwegianGreenland and western Barents Seas. U.S. Naval Res. Lab., Washington, D.C.

Rex, D. C., Gledhill, A. R., Brooks, C. K. \& Steenfelt, A. 1979: Radiometric ages of Tertiary salic intrusions near Kong Oscars Fjord, East Greenland. Rapp. Gronlands geol. Unders. 95, 106-109.

Roberts, D. G., Montadert, L. \& Searle, R. C., 1979: The western Rockall Plateau: Stratigraphy and structural evolution. Initial Rep. of the Deep Sea Drilling Project, 48, 1061-1088.

Risum, J. B. in press: Project NAD - Part 2. A marine geophysical project offshore East Greenland. Rapp. Gronlands geol. Unders. 100, 99-101.

Rønnevik, H. C. \& Motland, K. 1979: Geology of the Barents Sea. Proceedings, Norwegian Sea Symposium, Tromsø 1979. NSS/15, 1-34. Norwegian Petroleum Society, Oslo.

Secher, K., Leth Nielsen, B. \& Steenfelt, A. 1976: Uraniferous hydrocarbons (carburan) associated with Devonian acid volcanic rocks, Randbøldal, northern East Greenland. Rapp. Grønlands geol. Unders. 80, 112-115. 
Sommerhoff, G. 1973: Formenschatz und morphologische Gliederung des südostgrönländischen Shelfgebietes und kontinentale Abhanges. "Meteor" Forschungs-Ergebnisse C15, 1-54.

Soper, N. J. \& Costa, L. I. 1976: Palynological evidence for the age of Tertiary basalts and post-basaltic sediments at Kap Dalton, central East Greenland. Rapp. Gronlands geol. Unders. 80, 123-127.

Soper, N. J., Higgins, A. C., Downie, C., Matthews, D. W. \& Brown, P. E. 1976: Late Cretaceous - early Tertiary stratigraphy of the Kangerdlugssuaq arēa, East Greenland, and the age of the opening of the north-east Atlantic. J. geol. Soc. London 132, 85-104.

Surlyk, F. 1977a: Stratigraphy, tectonics and palaeogeography of the Jurassic sediments of the are as north of Kong Oscars Fjord, East Greenland. Bull. Gronlands geol. Unders. 123, $56 \mathrm{pp}$.

Surlyk, F. 1977b: Mesozoic faulting in East Greenland. In R. T. C. Frost \& A. J. Dikkers (edit.) Fault tectonics in NW Europe. Geologie en Mijnbouw 56, 311-327.

Surlyk, F. 1978a: Submarine fan sedimentation along fault scarps on tilted fault blocks (Jurassic-Cretaceous boundary, East Greenland). Bull. Gronlands geol. Unders. 128, $108 \mathrm{pp}$.

Surlyk, F. 1978b: Jurassic basin evolution of East Greenland. Nature 274, 130-133.

Surlyk, F., Clemmensen, L. \& Larsen, H. C. in press: Post-Palaeozoic evolution of the East Greenland continental margin. Mem. Can. Ass. petrol. Geol. 7.

Talwani, M. \& Eldholm, O. 1972: Continental Margin off Norway: A Geophysical Study. Bull. geol. Soc. of Amer., 83, 3375-3606.

Talwani, M. \& Eldholm, O. 1977: Evolution of the Norwegian-Greenland Sea. Bull. geol. Soc. Amer. 88, 969-999.

Talwani, M. \& Udintsev, G. 1976: Tectonic synthesis. Initial Report of the Deep-Sea Drilling Project 38, 1213-1242.

Vischer, A. 1943: Die postdevonische Tektonik von Ostgrönland zwischen $74^{\circ}$ und $75^{\circ}$ n.Br., Kuhn $\emptyset$, Wollaston Forland, Clavering $\emptyset$ und angrenzende Gebiete. Meddr Gronland 133, 1, 195 pp.
Wager, L. R. 1934: Geological investigations in East Greenland. I. General geology from Angmagssalik to Kap Dalton. Meddr Gronland 105, 2, 1-46.

Wager, L. R. 1935: Geological investigations in East Greenland. II. Geology of Kap Dalton. Meddr Gronland 105, 3, $32 \mathrm{pp}$.

Wager, L. R. 1947: Geological investigations in East Greenland. IV. The stratigraphy and tectonics of Knud Rasmussens Land and the Kangerdlugssuaq region. Meddr Gronland 134, 5, 64 pp.

Wager, L. R. \& Deer, W. A. 1938: A dyke swarm and coastal flexure in East Greenland. Geol. Mag. 75, 39-46.

Vail, P. R., Mitchum, R. M. Todd, R. G., Widmier, J. M., Thompson, S., Sangree, J. B., Bubb, J. W. \& Hatlelid, W. G. 1977: Seismic Stratigraphy and Global Changes of Sea Level. In Seismic Stratigraphy - Applications to Hydrocarbon Exploration. Amer. Ass. Petr. Geol., Mem. 26, 49-212.

Watt, M. 1975: Photoreconnaissance of the Blosseville Kyst between Steward $\emptyset$ and Søkongens Bugt, central East Greenland. Rapp. Gronlands geol. Unders. 75, 91-95.

Watt, W. S., Emeleus, C. H. \& Watt, M. 1972: Preliminary report on the basalts of Volquart Boons Kyst, East Greenland. Rapp. Gronlands geol. Unders. 48, 75-83.

Wenk, E. 1961: Tertiary of Greenland. [East Greenland]. In G O. Raasch (edit.) Geology of the Arctic 1, 278-284. Toronto U.P.

Vogt, P. R. \& Avery, O. E. 1974: Detailed Magnetic Surveys in the Northeast Atlantic and Labrador Sea.J. Geophys. Res. 79, 363-389.

Vogt, P. R., Johnson, G. L. \& Kristjansson, L. 1980; Morphology and Magnetic Anomalies North of Iceland. In Jacoby, W., Björnsson, A. \& Möller, D. (edit.) ICELAND - Evolution, Active Tectonics and Structure. J. Geophys. $47,67-80$.

Voppel, D., Srivastava, S. P. \& Fleischer, V., 1979: Detailed magnetic measurements south of the Iceland-Faroe Ridge. Dt. hydrogr. Z. 32, 154-172.

Ziegler, P. A. 1978: North-western Europe: Tectonics and Basin development. Geologie en Mijnbouw 57, 589-626. 